\title{
CARACTERIZACIÓN DOS ESPAZOS DOMÉSTICOS CULINARIOS DA ÉPOCA ROMANA EN GALICIA*
}

\author{
AdOLFo FERNÁNDEZ FERNÁNDEZ \\ Universidade de Vigo
}

ORCID iD: http://orcid.org/0000-0003-2981-6604

Alba A. Rodríguez NóvoA

Universidade de Vigo

ORCID iD: http://orcid.org/0000-0001-8577-212X

ROBERTO BARTOLOMÉ ABRAIRA

Engobe Arqueología e Universidade de Vigo

ORCID iD: http://orcid.org/0000-0002-6639-0764

\author{
Patricia VAlle Abad \\ Universidade de Vigo
}

ORCID iD: http://orcid.org/0000-0002-3080-614X

FERMÍn E. PÉREZ LOSADA

Universidade de Vigo

ORCID iD: http://orcid.org/0000-0001-8554-9542

Nerea Ruanova Álvarez

Universidade de Vigo

ORCID iD: http://orcid.org/0000-0001-7070-3295

* Agradecementos: Queremos agradecerlles ás seguintes persoas as informacións achegadas para elaborar este artigo: a Juan L. Naveiro López (Cambre); a Celso Rodríguez Cao (domus do MitreoLugo); ao Servizo de Arqueoloxía da cidade de Lugo, nas persoas de Enrique González Fernández e Covadonga Carreño Gascón (espazos culinarios da cidade de Lugo); a Santiago Ferrer Sierra (Xeral Tella-Lugo); e a Manuel Xusto Rodríguez (Riocaldo). Tamén lles agradecemos aos concellos de Allariz e de Vigo o seu apoio para levar a cabo as sucesivas campañas de escavacións na Cibdá de Armea e na villa de Toralla, respectivamente. Adolfo Fernández Fernández conta coa financiación dun contrato Ramón y Cajal (8RYC2018-024131-I).

Copyright: (C) 2021 CSIC. La edición electrónica de esta revista se distribuye bajo los términos de una licencia de uso y distribución Creative Commons Reconocimiento 4.0 Internacional (CC BY 4.0).

Cómo citar/Citation: Adolfo Fernández Fernández, et al., "Caracterización dos espazos domésticos culinarios da época romana en Galicia", Cuadernos de Estudios Gallegos, 68, núm. 134 (2021), págs. 47-90, https://doi.org/10.3989/ceg.2021.134.02 


\section{CARACTERIZACIÓN DOS ESPAZOS DOMÉSTICOS CULINARIOS DA ÉPOCA ROMANA EN GALICIA}

\section{RESUMO}

Este estudo ten como obxectivo caracterizar os espazos culinarios das vivendas romanas no actual territorio galego. Para isto, recompílanse un total de corenta espazos domésticos con funcións culinarias de xacementos de diversa tipoloxía. Posteriormente, analízanse en detalle sete casos concretos, algúns inéditos ata o momento. Por último, a partir do catálogo de cociñas e dos estudos de caso, coméntanse os exemplos recompilados en relación cos demais espazos que conforman a vivenda; así como a súa distribución interna e os principais elementos que a compoñen. O resultado móstranos uns espazos multifuncionais onde se desenvolven tarefas como o cociñado de alimentos, o ciclo do pan ou actividades téxtiles. Son espazos complexos relacionados co resto da vivenda, pero baixo parámetros precisos que garantan salubridade e seguridade. Este traballo achega unha visión innovadora, apoiada nunha nova lectura dos datos arqueolóxicos, que se afasta de estereotipos existentes sobre estes espazos da vivenda romana.

PALABRAS ClAVE: Gallaecia, época romana, casa romana, cociña, forno de pan e fogar.

\section{CARACTERIZACIÓN DE LOS ESPACIOS DOMÉSTICOS CULINARIOS DE LA ÉPOCA ROMANA EN GALICIA}

\section{RESUMEN}

Este estudio tiene como objetivo caracterizar los espacios culinarios de las viviendas romanas en el actual territorio gallego. Para esto, se han recopilado un total de cuarenta espacios domésticos con funciones culinarias de yacimientos de diversa tipología. Posteriormente, se analizan en detalle siete casos concretos, entre ellos algunos inéditos hasta el momento. Por último, a partir del catálogo de cocinas y de los estudios de caso, se comentan los ejemplos recopilados en relación a los demás espacios que conforman la vivienda; así como su distribución interna y los principales elementos que la componen. El resultado nos muestra unos espacios multifuncionales en los que se desarrollan tareas como el cocinado de alimentos, el ciclo del pan o actividades textiles. Son espacios complejos que se relacionan con el resto de la vivienda, pero bajo parámetros precisos que garantan la salubridad y seguridad. Este trabajo aporta una visión innovadora, apoyada en una nueva lectura de los datos arqueológicos, que se aleja de los estereotipos existentes sobre estos espacios de la vivienda romana.

PALABRAS ClAVE: Gallaecia, época romana, casa romana, cocina, horno de pan y hogar.

\section{CHARACTERIZATION OF DOMESTIC COOKING SPACES OF THE ROMAN PERIOD IN GALICIA}

\section{ABSTRACT}

This study aims to characterize the cooking spaces of Roman houses in the present-day territory of Galicia, gathering information from a total of forty domestic spaces with cooking facilities, from sites with different typologies. Furthermore, seven cases were analysed individually in detail, including some unpublished sites. Finally, by combining the data from the catalogue and the individual cases, the examples of cooking areas are discussed in relation to the other domestic spaces of the dwellings, as well as their interior layout and the major elements that comprise them. The results reveal the existence of multifunctional spaces, where different tasks are carried out, such as food preparation, bread baking and textile activities. They are complex spaces, connected to the rest of the house, but with specific criteria, that guarantee their hygiene and safety. This work offers a new outlook on the issue, endorsed by a new interpretation of the archaeological data, that distances itself from previous stereotypes regarding these kinds of Roman domestic spaces.

KEY WORDS: Gallaecia, Roman period, Roman house, kitchen, bread kiln and fireside. 
Recibido/Received: 16/01/2020

Aceptado/Accepted: 09/11/2020

A cociña é, por así dicilo, a cinsenta da casa romana.

U. E. Paoli, Vita romana, Florencia, 1940 ${ }^{1}$

ta hoxe, non existen estudos monográficos sobre ambientes culinarios
da época romana en Galicia, e o seu estudo queda consignado a análi-
ses concretas dentro de traballos específicos de determinados edificios como Noville ou Toralla- ou en obras xerais de compendio. ${ }^{2}$ Recentemente, estes espazos tiveron certa atención ao ser incluídos dentro de estudos monográficos, especialmente os enfocados cara á produción de pan na época romana. ${ }^{3}$ No entanto, estes ambientes como tal non son habitualmente tratados de forma exclusiva como aquí pretendemos, senón sempre como parte da análise dunha vivenda ou parte dela, cun grao menor de atención fronte a complexos termais ou salóns e estancias nobres. Como mostra da pouca atención que teñen recibido por parte da investigación sobre a arquitectura doméstica, podemos sinalar dous recentes traballos en duas urbes romanas atlánticas como Conimbriga ${ }^{4}$ e Bracara Augusta 5 . Nestes traballos os espazos culinarios apenas son referenciados aludindo a que se tratan de espazos pouco visibles no rexistro arqueolóxico. Algo que, como veremos na nosa análise, choca cos abundantes datos cos que contamos en Galicia.

As memorias ou os informes técnicos de escavacións tampouco acostuman a prestarlle demasiada atención aos espazos culinarios. Na maioría dos casos, identifícase a presenza dun fogar ou zona de combustión cunha cociña, sen profundar na

\footnotetext{
1 En Pedro Ángel Fernández Vega, La casa romana, Madrid, Akal, 1999, páx. 226.

${ }^{2}$ Fermín PÉrez Losada, Entre a cidade e a aldea. Estudio arqueohistórico dos 'aglomerados secundarios 'romanos en Galicia, Brigantium, 13 (2002), páxs. 15-348.

3 Macarena Bustamante, Javier Salido e Eulalia Gijón: "La panificación en la Hispania romana", en Macarena Bustamante-Álvarez e Darío Bernal Casasola (coords.), Artifices idóneos: artesanos, talleres y manufacturas en Hispania, Madrid, CSIC, 2014 (Anejos de Archivo Español de Arqueología, 719), páxs. 333-368.

${ }^{4}$ Hipólito Virgilio Correia, A Arquitectura Doméstica de Conimbriga e as Estruturas Económicas e Sociais da Cidade Romana, Coimbra, Centro de Estudos Arqueológicos das Universidades de Coimbra e Porto, 2013 (Conimbriga, Anexos, 6).

${ }^{5}$ Fernanda Eugénia Puga de Magalhaes, A domus romana no Noroeste Peninsular. Arquitetura, construção e sociabilidades, Tese de doutoramento da Universidade do Minho, Braga, 2019.
} 
análise, o que pode provocar a incorrecta interpretación destes espazos. Pese a isto, puidemos establecer que, a partir dos datos existentes, ata en corenta casos o(s) citado(s) fogar(es) formaba(n) parte dun espazo culinario máis ou menos complexo. Descartamos todos os dubidosos, polo que a cifra sería lixeiramente superior se finalmente estas estancias resultan ser cociñas. Tampouco incluímos cociñas en xacementos «tipo castro» a pesar de que somos conscientes de que na súa inmensa maioría presentan niveis da época romana e que a súa análise multiplicaría os exemplos. A causa da nosa decisión radica en que, na maior parte dos casos, os estudos destes xacementos presentan deficiencias no rexistro cronoestratigráfico - ao tratarse en moitos casos de escavacións antigas-, polo que nos poderían achegar datos pouco fiables para alcanzar o noso obxectivo final: a caracterización dos espazos culinarios da época romana na actual Galicia.

Para este estudo acoutouse unha área xeográfica administrativa actual, a comunidade autónoma galega (noroeste peninsular). Esta elección do marco xeográfico responde ás facilidades de acceso dos datos, especialmente aos informes e ás memorias técnicas, centralizadas no Servizo de Arqueoloxía da Xunta de Galicia. Por isto, a nosa análise abrangue a totalidade do Conventus Lucensis e parte dos Conventus Bracarensis e Asturicensis da provincia baixo imperial romana da Gallaecia. A pesar de non incorporar a totalidade da antiga provincia, neste territorio atopamos unha boa mostra da tipoloxía de xacementos habitacionais da época romana: cidades (Lugo), núcleos de poboación de tipo «aglomerado secundario» (p. ex. Iria Flavia, Xinzo ou Armea), villae rurais do interior (p. ex. Agro de Nogueira, Porta de Arcos ou Aquis Originis) ou xacementos para a explotación dos recursos mariños como villae costeiras e factorías de salga (p. ex. Bueu, Toralla, Noville ou Caldoval).

Con estes antecedentes e aclaracións previas, o estudo estrutúrase en tres partes:

- A primeira, consignada a presentar, en forma de catálogo, os ambientes culinarios romanos na actual Galicia. Cada xacemento inclúe a súa localización actual (provincia, concello e coordenadas), o conventus, o tipo de xacemento (cidade, aglomerado secundario, villa etc.) e as referencias bibliográficas. Séguelle unha breve descrición do(s) espazo(s) culinario(s). Só nalgúns casos (Noville, Agro de Nogueira, as domus lucenses do Mitreo, Armanyá e Pazo Lomas e Bueu), a descrición acompáñase de imaxes/ planimetrías, ao seren casos importantes para a análise interpretativa.

- Na segunda parte analízanse en detalle sete casos que poderían funcionar como modelos válidos para a realidade romana deste territorio: dúas $\mathrm{cu}$ linae de domus urbanas da capital Lucus; os ambientes culinarios de dúas domus de Armea, un aglomerado secundario alto imperial do interior da Gallaecia; o espazo doméstico da villa-mansio de Aquis Originis e as culinae dos edificio da villa tardoantiga e costeira de Toralla.

- Por último, e a partir dos datos do catálogo e dos casos de estudo, sintetízase e interprétase a información co obxectivo de achegarse á realidade deste tipo de espazos na rexión de estudo. 
Neste punto cómpre aclarar a diferenza no noso estudo entre os termos «forno» e «fogar». Cando nos referimos a fornos (furnus), estamos a falar dunha estrutura sobreelevada e cuberta por unha bóveda de obra cuxa finalidade é a de cociñar alimentos. En ningún caso se trata de fornos cerámicos, nos que existe unha separación entre a cámara de combustión e a de cocción/laboratorio mediante unha grella. Por «fogar» ou «lareira» entendemos un tipo de estruturas macizas, construídas con materiais diversos, e de formas variadas, situadas a rentes do chan e sen cobertura de obra.

\section{CATÁlogo DE COCiÑAS}

Como sinalamos anteriormente, catalogáronse corenta espazos culinarios nas catro provincias galegas. Cada caso presenta unha problemática diferente debido ao grao de información existente. Algunhas estancias culinarias atópanse totalmente escavadas e a súa identificación é clara, mesmo contamos con datos

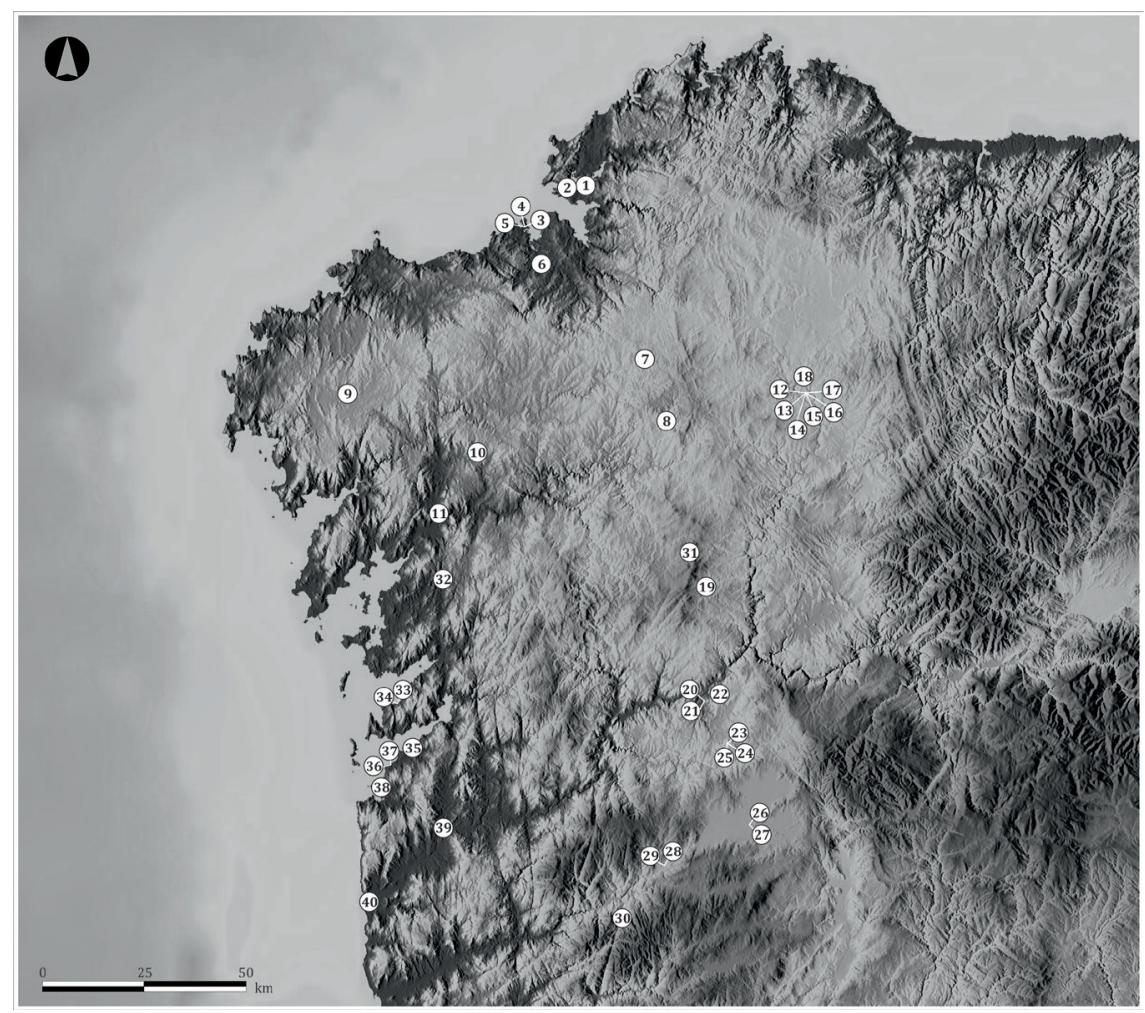

Fig. 1. Mapa coa localización das 40 cociñas romanas identificadas. 
dos fogares e a cultura material asociada ao espazo culinario. Noutros, os datos son moito máis escasos, aínda que a súa identificación como cociña parece clara. Por último, incluímos algúns dubidosos que cremos, polos datos existentes, que poderían ser cociñas. Non engadimos aquí os espazos que presentaban máis incerteza, especialmente aqueles con cronoloxía dubidosa e outros dos que só se sinalan áreas de queimado ou cinsas sen estruturas de combustión asociadas.

\section{A Coruña}

1. Noville. Conventus: Lucense. Concello: Mugardos. Coordenadas: X: 562584.56, Y: 4811741.89. Tipo de xacemento: villa. Datación: baixo imperial (finais do s. III-mediados do s.VI) ${ }^{6}$

No cuadrante sur occidental do edificio da villa de Noville localizouse unha zona que foi definida como de servizos e funcional, relacionada con labores de cociña (fig. 2, a). Foron exhumadas parcialmente dúas estancias interpretadas como culina. Na máis extensamente escavada atopáronse, na esquina sur oriental, os restos dun forno doméstico. O pavimento era de terra pisada, con abundantes restos de lixos alimentarios, así como anacos cerámicos. O forno presentaba un baseamento circular macizo construído con laxes de xisto, sobreelevado sobre o pavimento. Estaría cuberto por unha bóveda, da que se pode ver aínda o seu arrinque. $\mathrm{O}$ fogar do forno era de ladrillos e conservaba a base da boca de alimentación sinalada por un gran canto rodado e varios cachotes de grandes dimensións (fig. 2, b). Na estancia anexa, ao sur do forno (fig. 2, a), identificouse un fogar rectangular delimitado por ladrillos e laxes de xisto. A prancha tamén era de ladrillos. Estas estancias da cociña localizáronse anexas ao espazo termal localizado no lateral leste da villa, que se identificaría coa parte servizal.

2. Mugardos-Caldoval. Conventus: Lucense. Concello: Mugardos. Coordenadas: X: 559878.80, Y: 4811944.09. Tipo de xacemento: villa. Datación: alto e baixo imperial (s. I-V) ${ }^{7}$

\footnotetext{
${ }^{6}$ Fermín Pérez losada, Juan Naveiro López, Francisco Doval Galán, Ladislao Castro Pérez, José Manuel VÁzquez VARela e Carlos Fernández Rodríguez, "Estudio do material arqueolóxico procedente da vila romana de Noville (Mugardos, A Coruña)", Minius, 1 (1992), páxs. 57-88; Fermín PÉrEZ LOSADA, "Escavación arqueolóxica, prospección xeofísica e consolidación da vila romana de Noville (Mugardos, A Coruña)", en Arqueoloxía-Informes 3. Campaña 1989, Santiago de Compostela, Xunta de Galicia, 1995, páxs. 51-56; Fermín PÉrez LosAdA, "Xacemento de Noville: unha villa romana costeira na villa de Ferrol", Brigantium, 12 (2000), páxs. 219-226.

7 Susana Ricart Gulllot, El yacimiento romano de Caldoval, Mugardos, A Coruña, 2014 [memoria técnica depositada no Servizo de Arqueoloxía da Dirección Xeral do Patrimonio Cultural da Xunta de Galicia].
} 
$\mathrm{Na}$ zona noroeste do xacemento localízase a denominada como estancia 11, que parece corresponder cunha cociña, ao documentarse un fogar rectangular pegado á parede. Os laterais están construídos con laxes de granito e a base é de ladrillos. Non se asenta directamente sobre o muro, senón que presenta unha estrutura separada mediante grandes perpiaños. O chan é de terra pisada. Está relacionada cunha serie de estancias domésticas dispostas en batería no lado norte dun gran patio.

Ao lado da estancia 11 atópase a estancia 10. Nun dos esquinais desta documentouse un forno construído cunha base de xisto, cos linteis da boca en perpiaño de granito e a bóveda en material latericio. O pavimento é de terra pisada, con restos de arxila rubefactada.

3. A Coruña-O Cantón Grande. Conventus: Lucense. Concello: A Coruña. Coordenadas: X: 548567.82, Y: 4802165.48. Tipo de xacemento: aglomerado secundario (Brigantium). Datación: alto e baixo imperial (s. I-VI) ${ }^{8}$

Nunha das estancias aparece, aínda que sen restos de queimado, unha base de fogar realizado con dúas tegulas asentadas sobre unha capa de arxila. Noutra habitación, encóntrase un fogar realizado cunha base de tegulas, catro pedras fincadas e unha lousa maior que podería estar destinada a un apoio de poste. Nesta última, apareceu tamén un muíño circular de man contra un dos muros.

4. A Coruña-Rúa de María Pita. Conventus: Lucense. Concello: A Coruña. Coordenadas: X: 548901.84, Y: 4802211.92. Tipo de xacemento: aglomerado secundario (Brigantium). Datación: alto imperial (mediados do s. I-finais do s. II) ${ }^{9}$

Os restos exhumados consisten nun edificio de planta rectangular dividida en tres espazos. Nun destes (de 5 x 6,2 m) aparece un posible fogar de ladrillos con restos dun buraco de poste asociado a unha pía de morteiro. Entre o material atopado destacan un muíño circular e varios pondera.

5. A Coruña-Rúa das Tabernas, 12: Conventus: Lucense. Concello: A Coruña. Coordenadas: X: 548950.79, Y: 4801862.68. Tipo de xacemento: aglomerado secundario (Brigantium). Datación: alto imperial (finais do s. II) ${ }^{10}$

\footnotetext{
${ }^{8}$ María Catalina López Pérez e Santiago VÁzquez Collazo, "La mesa y la villa romana de O Cantón Grande (A Coruña): aproximación al yacimiento a través de la Terra Sigillata”, Gallaecia, 26 (2007), páxs. 85-108.

9 Juan Luis NAVEIro López, "Arqueología urbana en A Coruña y definición del asentamiento romano", en Ramón Villares Paz (ed.), La ciudad y el mundo urbano en la historia de Galicia, Santiago de Compostela, Tórculo Eds., 1988, páxs. 35-62; PÉrEz LoSADA, “Entre a cidade e a aldea...”, páxs. 123-126.

${ }^{10}$ María Catalina López Pérez e Víctor Tomás Botella, "La vajilla fina de mesa de época romana en los solares núm. 10-12 de la calle Tabernas (A Coruña)”, Gallaecia, 29 (2010), páxs. 173-190; Samuel NióN ÁlVAREZ, "Brigantium no século XXI: aproximación aos últimos datos arqueolóxicos da ocupación galaicorromana na cidade de A Coruña (s. I-IV d. C.)”, Gallaecia, 37 (2018), páxs. 39-79.
} 
Formando parte dunha estancia, no seu lado leste, documentouse unha plataforma pavimentada con grandes lousas de xisto interpretadas como lareira. Esta lareira delimitaríase ao leste cun muro non conservado, que pecharía esta posible culina.

6. Cambre. Conventus: Lucense. Concello: Cambre. Coordenadas: X: 553024.15 Y: 4793370.16. Tipo de xacemento: villa. Datación: romana (s. I-V). Referencias: información directa de Juan L. Naveiro López, director da intervención

Documentouse un podio dun posible forno lindando coa área termal da villa.

7. Cidadela. Conventus: Lucense. Concello: Sobrado dos Monxes. Coordenadas: X: 577845.56, Y: 4770613.70. Tipo de xacemento: campamento militar. Datación: alto e baixo imperial (s. II-IV) ${ }^{11}$

Nos patios do campamento aparecen unha serie de fogares con forma rectangular. O material co que están construídos son maioritariamente tegulas en posición invertida, salvo un caso, no que se empregaron ladrillos. En 2009, exhumouse parte da cabeceira semicircular dun novo forno (posiblemente de pan) con paredes feitas, ben con tégulas e ladrillos, ben soamente con tegulas (cara arriba ou volteadas cara abaixo). Os arqueólogos especifican que as medidas deste tramo son aproximadamente $80 \mathrm{~cm}$ de longo por $1,8 \mathrm{~m}$ de ancho.

8. Agro de Nogueira. Conventus: Lucense. Concello: Toques. Coordenadas: X: 583500.00, Y: 4755330.00. Tipo de xacemento: villa. Datación: alto imperial ${ }^{12}$

$\mathrm{Na}$ esquina noroeste da villa localízanse tres estancias artelladas por un corredor que comunica á súa vez co gran patio central que organiza o resto da casa (fig. 2, c). A habitación central das tres identificouse como a cociña, xa que nela se documentou un forno nun dos seus esquinais. Este furnus ten planta de cuarto de círculo, a súa estrutura está construída con pedras irregulares -reenchidas por pedras e terra- e a súa prancha con tegulas volteadas (fig. 2, e). Conservaba o inicio do arrinque da bóveda construída con material latericio reaproveitado. No

\footnotetext{
11 José Manuel CaAmaño Gesto, "Excavaciones en el campamento de Cidadela (A Coruña)", Brigantium, 12 (2000), páxs. 199-208; Emilio RAMIL GonZÁleZ e José Manuel CAAMAÑo GeSTO, "Escavación arqueolóxica e limpeza no campamento romano de Cidadela. Campaña 2009”, en Actuacións arqueolóxicas. Ano 2009, Santiago de Compostela, Xunta de Galicia, 2010, páxs. 47-48.

12 Gonzalo Meijde Cameselle e Fernando Acuña Castroviejo, Memoria preliminar de la $4^{a}$ campaña de excavaciones arqueológicas en el castro de A Graña, castro de Piñeiro y agro de Nogueira (Toques, A Coruña), 1990 [memoria inédita depositada na Biblioteca da Facultade de Xeografía e Historia da Universidade de Santiago de Compostela]; Gonzalo Meijide Cameselle e Fernando Acuña Castroviejo, Memoria preliminar de la $5^{a}$ campaña de excavaciones arqueológicas en el castro de A Graña y agro de Nogueira (Toques, A Coruña), 1991 [memoria inédita depositada no Servizo de Arqueoloxía da Dirección Xeral do Patrimonio Cultural da Xunta de Galicia].
} 
esquinal nordeste desta mesma estancia (fig. 2, d) apareceu o baseamento dunha estrutura rectangular contra os muros que puido funcionar como lareira ao estar, polo tanto, na cociña da casa. O seu pavimento é a base dun groso opus signinum asentado sobre unha capa de laxes de xisto que se estende cara á estancia situada ao leste, á que se accede mediante un gran van aberto no centro da parede divisoria. Esta estancia presenta unha planta rectangular que conserva parte do pavimento en opus signinum na súa zona norte, namentres que no resto só se conservou a base de xisto froito, sen dúbida, de intensos labores agrícolas como o demostra a gran gabia que atravesa e perfora de leste a oeste a propia habitación. Contra o muro oeste documentouse unha estrutura cuadrangular de difícil interpretación ao atoparse baixo o nivel de pavimento (fig. 2, f). Aquí recuperouse unha pequena ara ao deus Mercurio (fig. 2, g). Por último, a habitación contigua á cociña polo oeste é de planta cuadrangular, con pavimento de terra pisada, e puido funcionar como lugar de almacenaxe, sen dúbida relacionada co ambiente culinario. No lateral leste da villa identificáronse zonas de combustión e incluso unha pequena lareira cuadrangular. Esta zona foi interpretada como unha área industrial da vivenda.

9. Brandomil. Conventus: Lucense. Concello: Zas. Coordenadas: X: 506179.30, Y: 4761911.84. Tipo de xacemento: aglomerado secundario (Glandimiro). Datación: alto imperial ${ }^{13}$

Faise referencia á presenza de elementos pétreos reutilizados nas casas da poboación actual, que formarían parte de fogares romanos.

10. Catedral de Santiago. Conventus: Lucense. Concello: Santiago de Compostela. Coordenadas: X: 537210.20, Y: 4747626.91. Tipo de xacemento: posible edificación doméstica-aglomerado secundario. Datación: romana indeterminada ${ }^{14}$

Na praza da Quintana aparecen unha serie de estancias con funcionalidade indeterminada (quizais doméstica). Nunha delas, atopouse un fogar e identificouse este espazo como cociña.

11. Iria-escavación do paso a nivel do ferrocarril. Conventus: Lucense. Concello: Padrón. Coordenadas: X: 528187.83, Y: 4732654.33. Tipo de xacemento: aglomerado secundario (Iria Flavia). Datación: alto e baixo imperial (s. I-VI) ${ }^{15}$

\footnotetext{
13 José Barreiro Barral, "Por tierras de Céltigos: Grandimirum o Brandomil", La Voz de Galicia (0711-1972); Pérez Losada, "Entre a cidade e a aldea...”, páxs. 292-295.

14 PÉREZ LosADA, "Entre a cidade e a aldea...”, páxs. 311-313.

${ }^{15}$ Luis Francisco López GonzÁlez e Yolanda ÁlvARez GonZÁlez, Informe preliminar da excavación en área no xacemento romano de Iria Flavia (Padrón, A Coruña), 1994; PÉREZ LosADA, "Entre a cidade e a aldea...", páx. 96.
} 
Nas estancias do lado leste dunha posible domus documentouse un fogar cuadrangular nun espazo identificado como a cociña, na que ademais se atoparon numerosos pondera. Separadas desta por unha rúa empedrada, apareceron outras estruturas cun forno circular, un fogar e unha base circular que se interpretou como mesa ou repisa.
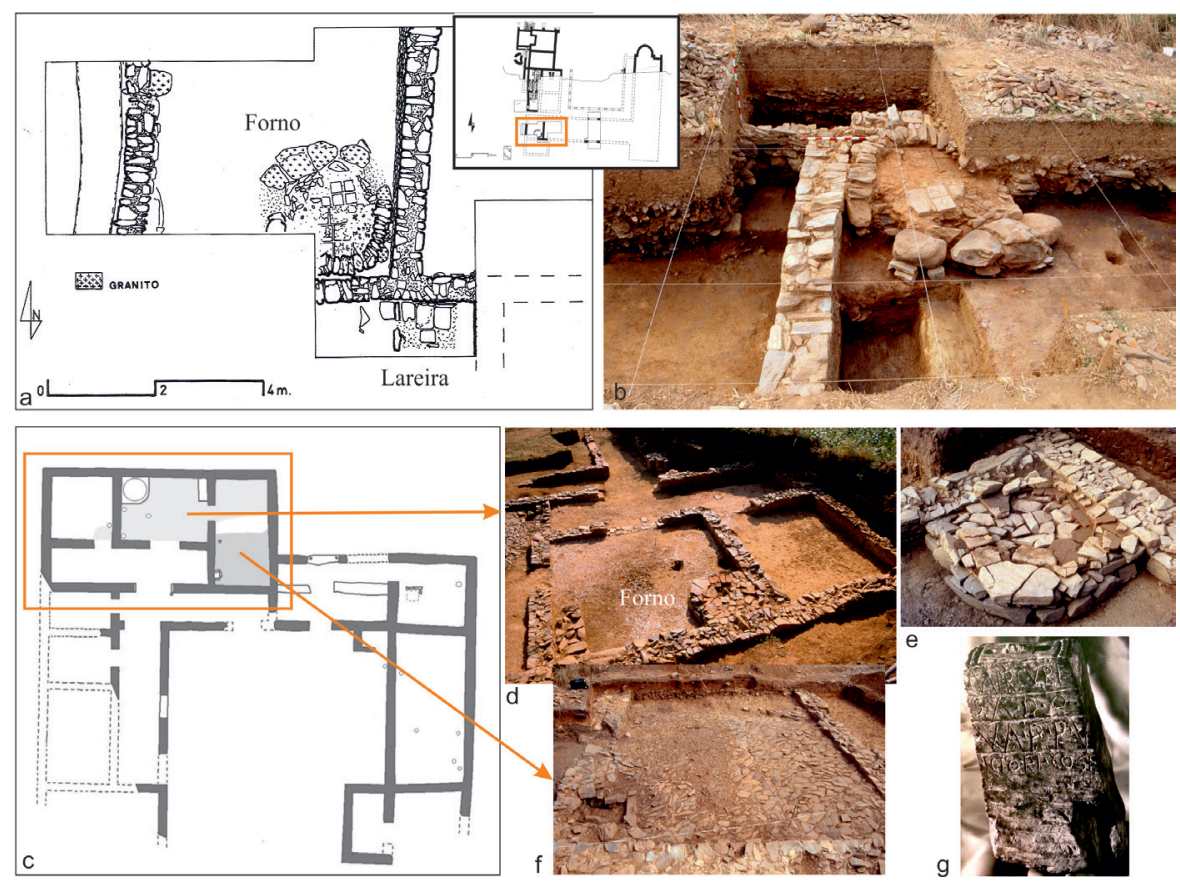

Fig. 2. a-b: Villa de Noville (Mugardos). c-g: Villa de Agro de Nogueira (Toques). Plantas ou Planos e fotos de F. Pérez Losada.

\section{Lugo}

12. Lugo-Rúa de Armanyá 10. Conventus: Lucense. Concello: Lugo. Coordenadas: X: 617383.59, Y: 4762884.15. Tipo de xacemento: cidade capital conventual (Lucus Augusti). Datación: baixo imperial ${ }^{16}$

\footnotetext{
${ }^{16}$ Enrique Alcorta Irastorza, LVCVS AVGVSTI. Vol. 2. Cerámica común romana de cocina y mesa hallada en las excavaciones de la ciudad, A Coruña, Fundación Pedro Barrié de la Maza, 2001 (Catalogación arqueolóxica e artística de Galicia); Antonio Rodríguez Colmenero, Lvcvs Avgvsti: la ciudad romano-germánica del Finisterre Ibérico. Génesis y evolución histórica (14 a. C.-711 d. C.), Lugo, Concello de Lugo, Servizo Municipal de Arqueoloxía, 2011.
} 
Nesta escavación documentouse unha domus que abría a súa fachada, precedida de beirarrúa porticada, cara ao decumanus maximus, polo seu lado norte. Na parte sueste localizouse unha pequena lareira. Estaba asentada sobre as cimentacións dun muro anterior, probablemente de época Flavia. Esta lareira aparecía sobre zócolo con muros de lousa, con forma ovalada duns 60-70 cms. De forma aproximadamente ovalada, o seu límite estaba marcado por unha parede (fig. 3, b). Estaba rechea por capas de carbonización entre as que apareceu, supostamente a modo de apoio, unha pequena ara de Gallio Senior. As estruturas conservadas foron reestruturadas en época tardía, arrasando os vestixios anteriores, polo que a estratigrafía e os materiais asociados corresponden maioritariamente á etapa baixo imperial.

13. Lugo-Rúa Nova (núm. 19), Pazo Lomas. Conventus: Lucense. Concello: Lugo. Coordenadas: X: 617305.79, Y: 4762917.69. Tipo de xacemento: cidade capital conventual (Lucus Augusti). Datación: alto e baixo imperial ${ }^{17}$

Arredor dun tramo do cardinus localizáronse varias estruturas, con diversas datacións. A primeira das fases de ocupación relaciónase co primeiro nivel de calzada. As estruturas desta fase aparecen polo lado leste da calzada, delimitadas por un muro lonxitudinal e paralelo a ela, e conforman a planta dun pequeno edificio rectangular dividido en dúas estancias. Nunha destas habitacións conservábanse os restos dunha pequena lareira, relacionada cun considerable nivel de carbonización. Entre os materiais recuperados nesta fase destaca a presenza de T. S. Itálica, Sudgálica, lucernas, cerámica de paredes finas, cerámica común romana lucense de tradición indíxena, moedas, entre elas un depósito de caetras e un as de Claudio. Este material permite contextualizar esta fase de ocupación nun período que abrangue a primeira metade do século I d. C., que corresponde co período Xulio-Claudio.

Posteriormente, unha serie de reformas documentadas tanto na calzada coma nos propios edificios mostran a seguinte fase construtiva. Nesta fase tamén aparecen pavimentos de opus signinum de boa calidade e outros de terra apisoada. Nunha das habitacións atopouse unha lareira localizada en posición central (fig. 3 , d). Entre a cultura material asociada a esta segunda fase destaca o importante volume de material cerámico, como TSH (con numerosos exemplares das formas Drag. 15/17 e Drag. 37), así como cerámica común moi variada, cerámica pintada, morteiros, vidros e numismas, entre eles, de Traxano, Domiciano ou Adriano. Esta segunda fase dátase entre a importante reforma construtiva Flavia e o século IV d. C.

\footnotetext{
17 Enrique GonzÁLEz FernÁNDEZ, Excavación arqueolóxica de urxencia no soar da Rúa Nova, 19, esquina da Rúa da Tinería, Lugo. Informe preliminar e valoración científica, 1992 [informe depositado na Dirección Xeral de Patrimonio Cultural da Xunta de Galicia].
} 
14. Lugo-Rúa Nova (núms. 68-72). Conventus: Lucense. Concello: Lugo. Coordenadas: X: 617358.13, Y: 4763204.91. Tipo de xacemento: cidade capital conventual (Lucus Augusti). Datación: baixo imperial ${ }^{18}$

15. Lugo-Domus do Mitreo-Vicerreitoría da USC. Conventus: Lucense. Concello: Lugo. Coordenadas: X: 617418.34, Y: 4762837.22. Tipo de xacemento: cidade capital conventual (Lucus Augusti). Datación: alto imperial ${ }^{19}$

$\mathrm{Na}$ escavación do soar para o edificio da Vicerreitoría da Universidade de Santiago de Compostela en Lugo, apareceu unha domus de dúas alturas con patio ao redor do cal se dispoñen as estancias. No lado norte deste espazo escavouse en parte unha posible lareira sobreelevada cun corpo de laxes de xisto e fogar de ladrillos (de tipo lidium) (fig. 3, a). Ten unha planta rectangular e está contra unha esquina en dous dos seus lados. Tanto a planta (rectangular) coma a total ausencia de indicios de bóveda lévanos a interpretar esta estrutura como un fogar. Está asociado á zona das latrinas.

16. Lugo-Rúa do Xeral Tella, esquina rúa de Ribadeo. Conventus: Lucense. Concello: Lugo. Coordenadas: X: 617335.28, Y: 4762479.7. Tipo de xacemento: cidade capital conventual (Lucus Augusti). Datación: alto imperial ${ }^{20}$

17. Lugo-Campo da Forca II. Conventus: Lucense. Concello: Lugo. Coordenadas: X: 617131.57, Y: 4763133.79. Tipo de xacemento: cidade capital conventual (Lucus Augusti). Datación: baixo imperial ${ }^{21}$

Nunha intervención de sondaxes en dúas campañas, localizouse un edificio (no denominado recinto $\mathrm{F}$ ) con pavimento de terra batida e unha lareira de forma semicircular contra o muro norte (fig. 3, c). Estaba conformada por pequenas lousas imbricadas entre si. Probablemente sufriu unha remodelación coa colocación de dúas grandes tégulas reaproveitadas no seu interior conformando unha nova prancha e modificando a forma ovalada por rectangular. Mostra claros indicios de contacto co lume e ao seu redor apareceron abundantes sinais de carbo-

\footnotetext{
18 Roberto Bartolomé Abraira, Enrique Alcorta Irastorza e Guillermo Santamaría GÁmez, "Escavación arqueolóxica en área dos soares núms. 68-70 da Rúa Nova en Lugo, avance de resultados", CROA: Boletín da Asociación de Amigos do Museo do Castro de Viladonga, 20 (2010), páxs. 24-25 (véxase o caso de estudo 3.6. Lugo-Rúa Nova, fig. 8, a-d).

${ }^{19}$ Celso Rodríguez Cao (coord.), A Domus do Mitreo, Santiago de Compostela, Universidade de Santiago de Compostela, 2011.

20 Santiago Ferrer Sierra e Enrique GonzÁlez Fernández, Memoria da escavación arqueolóxica de urxencia no soar da rúa do Xeral Tella, esquina rúa de Ribadeo, da cidade de Lugo. 1992, 1992 [informe depositado na Dirección Xeral de Patrimonio Cultural da Xunta de Galicia] (véxase o caso de estudo 3.7. Lugo, rúa do Xeral Tella, fig. 8, e-h).

${ }^{21}$ Covadonga CARReño GASCón, Campaña de excavación arqueológica en el Campo da Forca. Lugo. 1990, 1990 [informe depositado na Dirección Xeral de Patrimonio Cultural da Xunta de Galicia].
} 

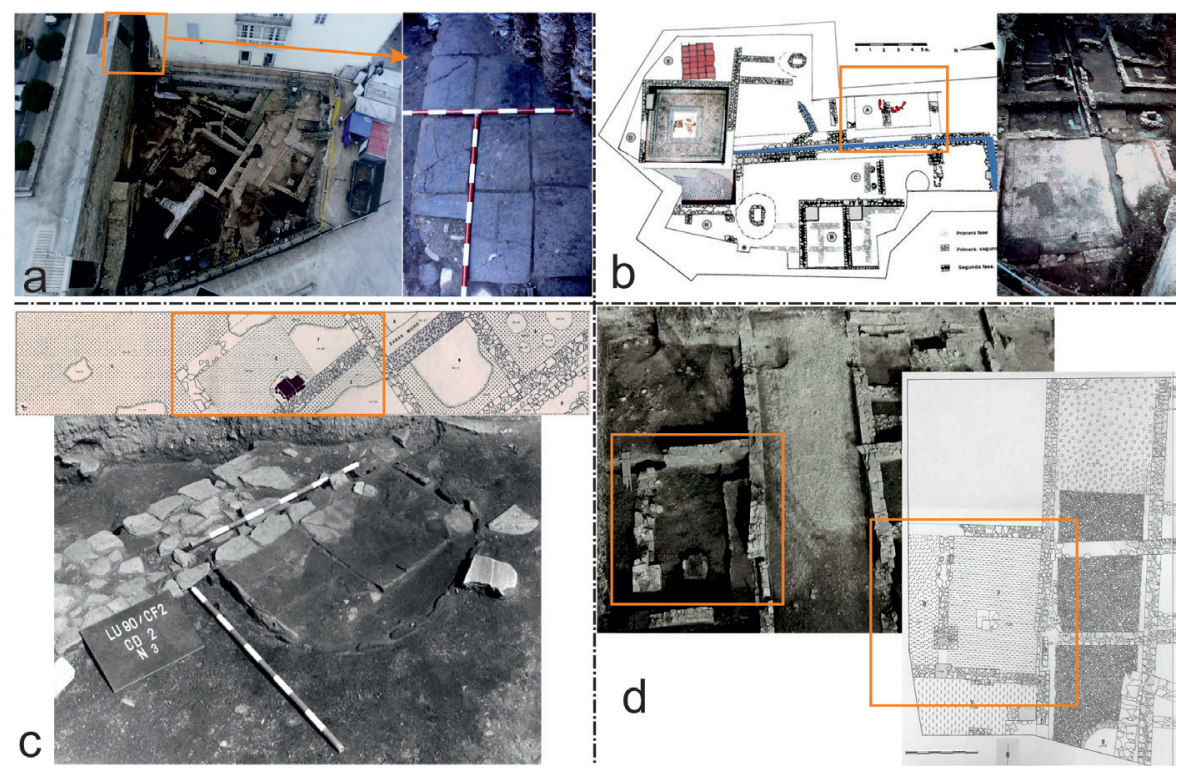

Fig. 3. Cociñas de Lugo. a: domus do Mitreo (cortesía de C. Rodríguez Cao). b: Armanyá (Servizo de Arqueoloxía do Concello de Lugo). c: Campo da Forca (Servizo de Arqueoloxía do Concello de Lugo). d: Pazo Lomas (Servizo de Arqueoloxía do Concello de Lugo).

nización. No lado sur, esta lareira aparece delimitada por pequenos fragmentos de tégulas fincadas. Os materiais aparecidos nestas estancias apuntan a unha cronoloxía baixo imperial.

18. Lugo-Antigo matadoiro. Conventus: Lucense. Concello: Lugo. Coordenadas: X: 616883.34, Y: 4765687.22. Tipo de xacemento: cidade capital conventual (Lucus Augusti). Datación: alto imperial ${ }^{22}$

No interior dunha estancia cun chan de arxila apisoada, atopouse un ladrillo rubefactado que se interpreta como parte dun posible fogar.

19. Quinta de Agrade. Conventus: Lucense. Concello: Chantada. Coordenadas: X: 593568.34, Y: 4715288.73. Tipo de xacemento: villa. Datación: baixo imperial $(\mathrm{s} . \mathrm{IV}-\mathrm{V})^{23}$

\footnotetext{
22 Covadonga Carreño Gascón, "Memoria de los sondeos arqueológicos realizados en el entorno del antiguo matadero municipal, Lugo", Larouco: Revista Anual da Antiguidade Galaica, 5 (2010), páx. 128. ${ }^{23}$ Luis Francisco LóPEZ GONZÁLEZ, Memoria da excavación de urxencia no xacemento romano de Quintá de Agrade (Chantada, Lugo), 1991 [memoria inédita depositada no Servizo de Arqueoloxía da Dirección Xeral do Patrimonio Cultural da Xunta de Galicia].
} 
$\mathrm{Na}$ cata 4 identificouse un espazo como a cociña da villa ao atoparse un fogar de ladrillos. O pavimento é de terra pisada e no exterior do muro habería un cabanel de madeira.

\section{Ourense}

20. Ourense-Colexio Xosefinas. Conventus: Lucense. Concello: Ourense. Coordenadas: X: 593445.25, Y: 4687490.61. Tipo de xacemento: aglomerado secundario (Auria). Datación: alto e baixo imperial (s. II-IV) ${ }^{24}$

Ás estancias do lado leste, de reducidas dimensións e de planta irregular, atribuíuselles unha funcionalidade doméstica. Nunha delas, con piso térreo, aparece un fogar pétreo contra o muro. Noutra, recolleuse un fragmento de catilus. Nunha das estancias escavadas en 2007 advírtense pegadas do que podería ser un fogar.

21. Ourense-Casa dos Fornos-As Burgas. Conventus: Bracarense. Concello: Ourense. Coordenadas: X: 593518.92, Y: 4687523.38. Tipo de xacemento: aglomerado secundario (Auria)? Datación: alto imperial ${ }^{25}$

Nunha das estancias, localizáronse dous fornos que se interpretan como fornos para pan.

22. Ourense-Santomé. Conventus: Lucense. Concello: Ourense. Coordenadas: X: 596452.01, Y: 4689063.91. Tipo de xacemento: aglomerado secundario. Datación: baixo imperial ${ }^{26}$

En cada unha das dúas domus tardorromanas documentáronse fogares. $\mathrm{Na}$ casa de dúas plantas aparece un fogar na esquina dunha estancia de $7 \mathrm{~m}^{2}$. Está formado por un ladrillo bipedalis delimitado por outros ladrillos dispostos de lado. Na casa porticada aparece un fogar de grandes dimensións e de forma irregular delimitado por un muro, un afloramento rochoso e lousas de granito. Dado que este último se sitúa no corredor da fachada principal, non queda moi claro se podemos atribuírlle a este segundo espazo funcións de cociña.

\footnotetext{
${ }^{24}$ Luis ORERo GRANDAL, "Intervención arqueolóxica nas inmediacións das Burgas: patio do colexio das Josefinas", Boletín Auriense, 27 (1997), páxs. 107-146; PÉrez LosADA, "Entre a cidade e a aldea...”, páx. 168; Luis Orero GrandaL, "Actuacións arqueolóxicas na cidade de Ourense: colexio das Madres Xosefinas e Xardín do Posío", en Ourense. A cidade, da orixe ao século XVI, Ourense, Museo Arqueolóxico Provincial de Ourense, 2009, páx. 39.

25 José María Eguileta Franco e Celso Rodríguez Cao (coords.), Aqva, divi, vrbs. Auga, deuses e cidade. Escavacións arqueolóxicas nas Burgas (Ourense), Casa dos Fornos e Traseiras das rúas do Vilar, Cervantes e do Baño, Ourense, Concello de Ourense, 2012, páx. 100.

${ }^{26}$ Xulio Rodríguez GonzÁlez, Conxunto arqueolóxico de Santomé. Guía arqueolóxica, Ourense, Museo Arqueolóxico Provincial de Ourense, 2000, páx. 54.
} 
23. Armea-Domus da Roseta. Conventus: Bracarense. Concello: Allariz. Coordenadas: X: 599538.41, Y: 4677788.62. Tipo de xacemento: domusaglomerado secundario. Datación: alto imperial (época Flavia) ${ }^{27}$

24. Armea-Domus do Hexáscele. Conventus: Bracarense. Concello: Allariz. Coordenadas: X: 599538.41, Y: 4677788.62. Tipo de xacemento: domusaglomerado secundario. Datación: alto imperial (época Flavia) ${ }^{28}$

25. Armea-Monte do Señoriño. Conventus: Bracarense. Concello: Allariz. Coordenadas: X: 599432.39, Y: 4677466.13. Tipo de xacemento: edificio viario e/ou administrativo. Datación: alto imperial ${ }^{29}$

$\mathrm{Na}$ parte alta do xacemento consérvase un fogar nunha estancia semirrupestre. Está constituído por tegulas volteadas cara abaixo, asentadas sobre o nivel de uso da estancia e apoiadas contra o muro escavado na rocha. As tégulas apareceron enteiras, aínda que fragmentadas. Todos os fragmentos estaban in situ, a excepción da esquina inferior esquerda da tégula da esquerda, que estaba levantada, en posición vertical. A estancia (culina) parece comunicar con outra ao sur e ao leste cunha zona aberta que a separa da zona habitacional.

26. Xinzo de Limia-Santa Mariña: Conventus: Bracarense. Concello: Xinzo de Limia. Coordenadas: X: 605235.09, Y: 4657737.57. Tipo de xacemento: aglomerado secundario (Forum Limicorum). Datación: alto imperial $(\text { Flavio })^{30}$

Nunha das estancias atopouse abundante cerámica de cociña e de mesa, e unha posible base dun fogar ou forno, polo que foi interpretada como espazo culinario.

\footnotetext{
27 Carlos Hugo Barba Seara e David Pérez López, "O castro de Armea e a súa evolución na cultura castrexa: intervencións arqueolóxicas 2011 a 2014”, Boletín Auriense, 46 (2016), páxs. 59-102; Adolfo FERnÁNdez FERnÁndez e Fermín PÉrez Losada, A Cibdá de Armea I. Escavacións no xacemento galaico-romano do monte do Señoriño, Vigo, Servizo de Publicacións da Universidade de Vigo, 2017 (véxase o caso de estudo 3.2. Armea-Domus da Roseta, fig. 5, c-d).

28 Adolfo Fernández Fernández, Memoria interpretativa. Sondaxes arqueolóxicas e de conservación básica no castro de Armea (Allariz, Ourense). Campaña 2014, 2019 [memoria depositada no Servizo de Arqueoloxía da Xunta de Galicia] (véxase o caso de estudo 3.1. Armea-Domus do Hexáscele, fig. 5, a-b, e-g).

${ }^{29}$ Adolfo Fernández Fernández e Fermín Pérez Losada, A Cibdá de Armea I. Escavacións no xacemento galaico-romano do monte do Señoriño, Vigo, Servizo de Publicacións da Universidade de Vigo, 2017.

${ }^{30}$ Manuel Xusto Rodríguez, "O núcleo urbano de Xinzo e as súas orixes romanas”, en Antonio Rodríguez Colmenero (coord.), Los orígenes de la ciudad en el noroeste hispánico: actas del Congreso Internacional. Lugo, 15-18 de maio de 1996, Lugo, Deputación Provincial de Lugo, 1999, páxs. 1291-1304; PÉrez LosAdA, "Entre a cidade e a aldea...", páx. 217.
} 
27. Xinzo de Limia-Rúa de Romero Nieto. Conventus: Bracarense. Concello: Xinzo de Limia. Coordenadas: X: 605277.65, Y: 4657548.65. Tipo de xacemento: aglomerado secundario (Forum Limicorum). Datación: alto imperial (s. I-III) $)^{31}$

Documéntanse ata oito fogares construídos con tégulas volteadas cuxa función puido ser a de aquecer estes cubicula. Non obstante, algún deles parece que formou parte dun espazo exclusivamente de cociña.

28. Aquis Querquennis-Campamento. Conventus: Bracarense. Concello: Bande. Coordenadas: X: 584434.84, Y: 4647380.93. Tipo de xacemento: campamento. Datación: alto imperial (Flavio) ${ }^{32}$

Os barracóns dos soldados dispoñen en moitos casos dun fogar. Estes poden ser simples tegulas apoiadas no chan, unha ou varias tégulas/ladrillos delimitados por perpiaños ou tégulas/ladrillos apoiados en muros de pedra. Así mesmo, tamén se atopan zonas rubefactadas, que indican que os soldados poderían facer lumes fóra dos fogares. Nalgúns dos contubernia hai dous fogares, un en cada estancia, aínda que se descoñece se os utilizaban ao mesmo tempo ou a cociña foi trasladada de habitación. Con todo, o máis frecuente é que apareza un só fogar situado na habitación anterior, de menor tamaño. Nas estancias destinadas aos centurións, tamén se definen algúns espazos como cociñas. Neles atopamos fogares de similares características aos descritos. Nos casos nos que se especifican as medidas, os fogares oscilan entre os $30 \times 20$ $\mathrm{cm}$ e os $140 \times 85 \mathrm{~cm}$, e son frecuentes os de $80 \times 60 \mathrm{~cm}$. Os pavimentos destas estancias son de terra batida.

Ademais, apareceu unha base dunha plataforma con forma ovalada e restos dun muro relacionado cun dos barracóns e centrado respecto ao patio. Interprétase como un forno de pan usado pola centuria que vivía nese barracón. Cada centuria dispoñía dun destes fornos de planta circular ou oval, colocados na via sagularis ou perimétrica. Algunhas estancias do valetudinarium tamén estaban provistas de fogar, aínda que o máis probable é que funcionasen a modo de calefacción.

\footnotetext{
31 Eduardo Breogán NiETo MuÑIz, "Escavación arqueolóxica en área no soar núm. 5 da rúa de Romero Nieto, Xinzo de Limia”, en Actuacións arqueolóxicas. Ano 2007, Santiago de Compostela, Xunta de Galicia, 2009, páxs. 164-165.

32 Antonio Rodríguez Colmenero e Santiago Ferrer Sierra (eds.), Excavaciones arqueológicas en “Aquis Querquennis”. Actuaciones en el campamento romano (1975-2005), Lugo, Grupo Arqueolóxico Laurouco, 2006; Santiago Ferrer Sierra, "Escavación arqueolóxica no campamento romano de Aquis Querquennis, Bande (Ourense)", en Actuacións arqueolóxicas. Ano 2007, Santiago de Compostela, Xunta de Galicia, 2009, páxs. 54-55; Santiago FERRER SIERRA, "Recentes intervencións arqueolóxicas no campamento militar de Aquis Querquennis (Bande, Ourense)", Larouco, 5 (2010), páxs. 163-166.
} 
29. Aquis Querquennis-Mansio. Conventus: Bracarense. Concello: Bande. Coordenadas: X: 584395.95, Y: 4647754.79. Tipo de xacemento: mansio. Datación: alto imperial (primeira fase); tardorromana: IV-V (terceira fase) ${ }^{33}$

Na primeira fase de ocupación da mansio rexistrouse unha estancia rectangular cunha entrada frontal e nunha das esquinas posteriores un forno de pan de planta cadrada. Ten un tamaño de 1,9 x 1,8 m, cun receptáculo interior para as cinsas, fogar circular de tégulas e consérvase parte do arrinque da bóveda de cobertura (fig. 4, b). Ademais, na terceira fase da mansio constrúense unha serie de estancias e unha delas presenta un fogar no chan contra un dos muros, o que levou á interpretación deste espazo como a cociña (fig. 4, a).

30. Aquis Originis-Riocaldo. Conventus: Bracarense. Concello: Lobios. Coordenadas: X: 574198.41, Y: 4634422.95. Tipo de xacemento: villa. Datación: tardío (fin do s. II-V) $)^{34}$

\section{Pontevedra}

31. Porta de Arcos. Conventus: Lucense. Concello: Rodeiro. Coordenadas: X: 589378.41, Y: 4723733.37. Tipo de xacemento: villa. Datación: alto imperial (S. I-III) $)^{35}$

Nunha das estancias recolléronse numerosos fragmentos de materiais cerámicos de cociña, así como gran cantidade de restos de combustión asociados a un fogar con restos de rubefacción. Os arqueólogos interpretan este espazo como a cociña da villa.

32. Caldas de Reis-Rúa da Ferreiría. Conventus: Lucense. Concello: Caldas de Reis. Coordenadas: X: 529323.13, Y: 4716710.63. Tipo de xacemento: aglomerado secundario (Aquis Celenis). Datación: alto imperial (s. IV-V) ${ }^{36}$ Aparecen restos dun posible fogar asociado a un espazo doméstico.

\footnotetext{
${ }^{33}$ Antonio Rodríguez Colmenero, Santiago Ferrer Sierra e Francisco Hervés Reigoso, "El complejo arqueológico romano de Aquis Querquennis, Porto Quintela (Ourense)", en Antonio Rodríguez Colmenero (coord.), Los orígenes de la ciudad en el noroeste hispánico: actas del Congreso Internacional, Lugo, 15-18 de maio de 1996, Lugo, Deputación Provincial, 1999, páxs. 891-910; PÉrEz LosADA, "Entre a cidade e a aldea...", páxs. 188-189.

34 Manuel Xusto Rodríguez, “A villa romana de Riocaldo: estado da cuestión”, Brigantium, 12 (2000), páxs. 227-246. Véxase o caso de estudo 3.3. Aquis Originis-Riocaldo, fig. 6.

35 Erik CARlsson-Brandt FontÁn, "La villa romana de Porta de Arcos (Rodeiro, Pontevedra): 45 años de investigación arqueológica”, Férvedes, 8 (2015), páxs. 267-275.

${ }^{36}$ Nuria CALO Ramos, "Proxecto de excavación en área e control arqueolóxico no soar núm. 59 da rúa da Ferreiría", en Actuacións arqueolóxicas. Ano 2007, Santiago de Compostela, Xunta de Galicia, 2009, páxs. 179-180.
} 
33. Bueu-Factoría de salga. Conventus: Lucense. Concello: Bueu. Coordenadas: X: 518138.15, Y: 4686275.42. Tipo de xacemento: factoría de salga. Datación: baixo imperial (s. IV) 37

$\mathrm{Na}$ época baixo imperial a factoría reutilízase con funcións domésticas. Nunha das pías da factoría de salga de Montero Ríos, núm. 7, constrúese un fogar rectangular a rentes do chan, cuxa base era de tégulas volteadas (catro tegulas polo menos), polo que foi interpretado como unha cociña (fig. 4, d).

34. Bueu-villa? Conventus: Lucense. Concello: Bueu. Coordenadas: X: 518127.14, Y: 4686223.70. Tipo de xacemento: villa? Datación: romana ${ }^{38}$

Nunhas estancias de difícil interpretación situadas ao sur da factoría de salga e da olaría de ánforas, documentouse un gran forno circular para cocer pan situado nunha das súas esquinas. Conservaba parte do alzado da bóveda en tégula reutilizada. Xa que a escavación non foi completada, non podemos precisar máis datos

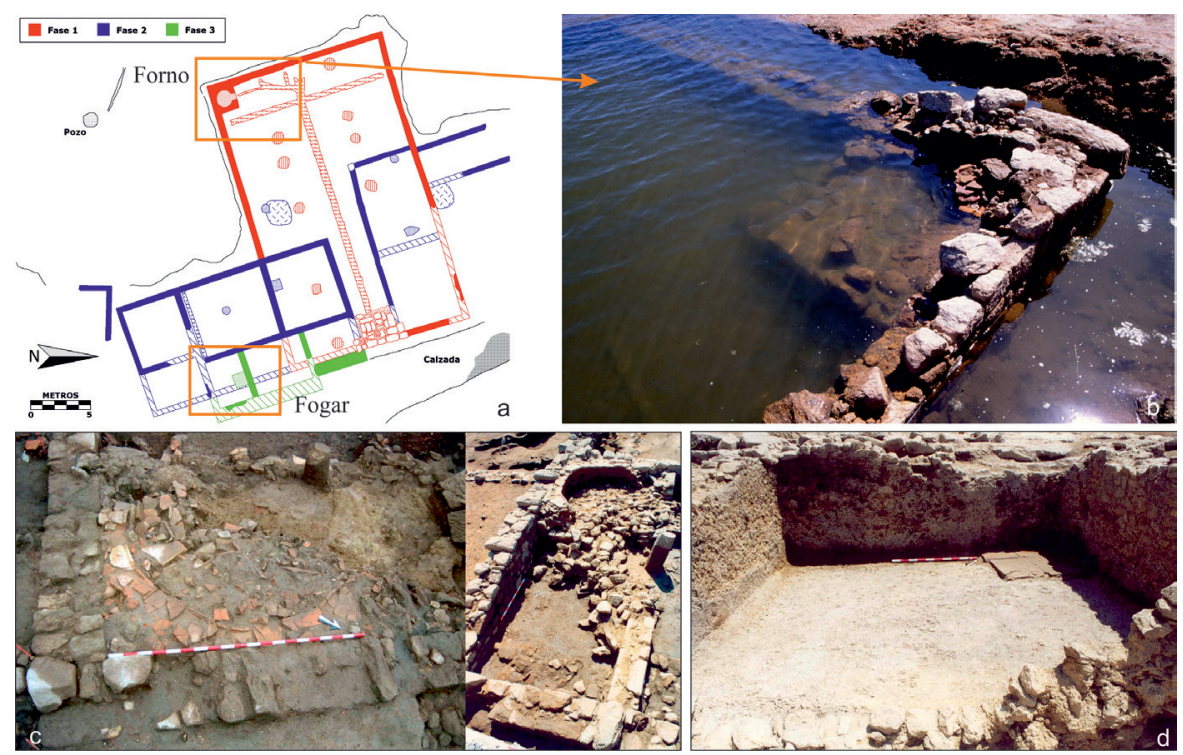

Fig. 4. Fig. 4. a-b: Planta ou Plano e foto do forno da mansio de Aquis Querquennis ${ }^{39}$. c: Forno da villa? de $\mathrm{Bueu}^{40}$. d: fogar no interior dun pío de salgaura da factoría de Bueu ${ }^{41}$.

\footnotetext{
${ }^{37}$ Fructuoso DíAz García, O mundo antigo no Museo Massó e a romanización en Bueu, Santiago de Compostela, Xunta de Galicia, 2015.

38 DíAz García, O mundo antigo no Museo Massó..., páxs. 72-91.

39 PÉrez LosadA, "Entre a cidade e a aldea...".

${ }^{40}$ Díaz García, O mundo antigo no Museo Massó...

41 Díaz García, O mundo antigo no Museo Massó...
} 
sobre esta estrutura, aínda que parece asociarse a outras dúas estancias onde se recuperaron muíños e outros elementos domésticos e/ou artesanais (fig. 4, c).

35. Vigo-Marqués de Valterra. Conventus: Bracarense. Concello: Vigo. Coordenadas: X: 522079.84, Y: 4675713.44. Tipo de xacemento: aglomerado secundario. Datación: baixo imperial $(\mathrm{IV}-\mathrm{V})^{42}$

Atópanse restos de estancias residenciais e de explotación. Interprétanse como cociñas aquelas nas que aparecen fogares.

36. Vigo-Toralla/edificio principal. Conventus: Bracarense. Concello: Vigo. Coordenadas: X: 516899.19, Y: 4671579.68. Tipo de xacemento: villa. Datación: tardorromana (IV-V) ${ }^{43}$.

37. Vigo-Toralla/edificio secundario. Conventus: Bracarense. Concello: Vigo. Coordenadas: X: 516899.19, Y: 4671579.68. Tipo de xacemento: villa. Datación: tardío (IV-V) ${ }^{44}$

38. Panxón-Tomás Mirambel, núm. 8. Conventus: Bracarense. Concello: Nigrán. Coordenadas: X: 514405.16, Y: 4666033.23. Tipo de xacemento: villa. Datación: alto e baixo imperial (II-IV) ${ }^{45}$

No contorno dun espazo produtivo localízanse unhas estancias domésticas. Nunha delas aparece un fogar de planta circular de $60 \mathrm{~cm}$ de diámetro, formado por unha cubeta semicircular que se reencheu de arxila e se tapou cunha tégula boca abaixo.

39. Tui-Rúa dos Loureiros. Conventus: Bracarense. Concello: Tui. Coordenadas: X: 529836.49, Y: 4656163.41. Tipo de xacemento: aglomerado secundario (Tude). Datación: baixo imperial (IV-VI) ${ }^{46}$

\footnotetext{
${ }^{42}$ Rosa María Paz Lobeiras, Memoria da escavación arqueolóxica en área no solar núm. 65 da rúa do Conde de Torrecedeira (Vigo), 1998 [memoria inédita depositada no Servizo de Arqueoloxía da Dirección xeral do Patrimonio Cultural da Xunta de Galicia], páx. 31.

${ }^{43}$ Fermín Pérez Losada, Santiago Vieito Covela e Adolfo Fernánez Fernández, "Resultados preliminares das escavacións arqueolóxicas na "villa" romana de Toralla (Oia, Vigo)", Castrelos: Revista do Museo Municipal Quiñones de León, 13 (2007), páxs. 12-25 (véxase o caso de estudo 3.4. Toralla-edificio principal, fig. 7, a-c).

${ }^{44}$ Pérez Losada, Vieito Covela e Fernánez Fernández, "Resultados preliminares...", páxs. 12-25 (véxase o caso de estudo 3.5. Toralla-edificio secundario, fig. 7, d-f).

${ }^{45}$ Rosa Villar Quintero, "Escavación arqueolóxica en área na rúa de Tomás Mirambel, núm. 8, Panxón, Nigrán”, en Actuacións arqueolóxicas. Ano 2006, Santiago de Compostela, Xunta de Galicia, 2008, páxs. 159-160.

46 Ángel AcuÑa Piñeiro, Fermín Pérez Losada e Rosa María Paz Lobeiras, "Nuevas aportaciones al Vigo romano", en Congreso Internacional "As orixes da cidade no noroeste hispánico”, comunicación oral non publicada en actas, 1996; PÉREZ LosADA, "Entre a cidade e a aldea...”, páxs. 61-86.
} 
Localizouse un horizonte habitacional no que se identifican polo menos tres edificacións domésticas. A primeira ten pegadas dun fogar sinxelo contra un muro e constituído por lousas planas delimitadas por lousas e tégulas fincadas.

40. Camposancos-Eira Vella, Saa. Conventus: Bracarense. Concello: A Guarda. Coordenadas: X: 511685.37, Y: 4637718.21. Tipo de xacemento: habitacional indeterminado. Datación: baixo imperial? ${ }^{47}$

$\mathrm{Na}$ ocupación tardoantiga deste xacemento aparecen unha serie de estruturas habitacionais de planta cuadrangular nas que se atopan pavimentos con restos de fogares.

\section{Casos de estudo}

\subsection{Armea-Domus do Hexáscele (fig. 5, a-b, e-g)}

O xacemento galaico-romano da Cibdá de Armea localízase no concello de Allariz (Ourense) (fig. 1). A ocupación humana sitúase sobre tres promontorios sucesivos na ladeira setentrional da montaña. Na terraza inferior, nunha parcela coñecida como A Atalaia, escaváronse nos anos cincuenta dúas domus galaicoromanas de patio interior, dispostas a ambos os lados dunha rúa empedrada. A Cibdá de Armea forma parte do denominado como «conxunto arqueo-histórico de Armea», xunto aos seguintes elementos: o Forno da Santa, sauna castrexa conservada como cripta baixo a inacabada basílica medieval da Ascensión; o xacemento galaico-romano semirrupestre do Monte do Señoriño, ${ }^{48}$ un asentamento habitacional a extra muros do castro construído a inicios do século I d. C. con posibles funcións administrativas; varios lagares rupestres de gran tamaño localizados nas ladeiras norte e noroeste da Cibdá, de indeterminada cronoloxía; e diversos achados de pezas pétreas claramente romanas -bases e fustes de columnas, epígrafe fragmentada- reutilizados nos paramentos das casas da aldea de Armea. A evidencia arqueolóxica (tamaño e localización, urbanismo, sauna, estatuaria etc.) permite cualificar a Cibdá de Armea como a probable capital na época romana do pobo dos interamnicos. ${ }^{49}$ En 2014, a Universidade de Vigo retomou as intervencións na terraza da Atalaia e actualmente pódense ver as dúas

\footnotetext{
${ }^{47}$ Brais Xosé Currás Refojos, Transformaciones sociales y territoriales en la cuenca del Baixo Miño entre la Edad del Hierro y la integración en el Imperio romano, tese de doutoramento, Santiago de Compostela, Universidade de Santiago de Compostela, 2012.

48 Adolfo Fernández Fernández e Fermín PÉrez LosAda, A Cibdá de Armea I. Escavacións no xacemento galaico-romano do Monte do Señoriño, Vigo, Servizo de Publicacións da Universidade de Vigo, 2017.

49 Fernández Fernández e Pérez losada, A Cibdá de Armea I, ...páx. 67.
} 
grandes domus totalmente escavadas. A que se sitúa ao norte da rúa empedrada coñécese como «domus do Hexáscele» e a que se sitúa ao sur como «domus da Roseta».

Na domus do Hexáscele atopamos unha habitación que se definiu como a cociña da casa, situada na esquina sueste do conxunto (fig. 5, a). Accédese á casa desde a rúa empedrada a través dun pequeno corredor, que dá acceso a un patio enlousado ao redor do cal se dispoñen as diversas estancias. No lado oeste, atopamos unha serie de espazos aos que resulta problemático asignar claramente unha funcionalidade, aínda que posiblemente se trata de habitacións e de salóns. No lado leste, as estancias parecen destinadas a actividades domésticas ou artesanais; é nesta área onde se localiza a cociña. A cociña sitúase de maneira independente do resto das habitacións. Accédese a ela a través do corredor que leva á rúa principal e está ao sur do patio empedrado da casa que artella toda a actividade neste extremo da vivenda.

Esta estancia foi definida como a cociña da domus debido á acumulación de elementos relacionados con esta actividade que presenta: un forno, un fogar e un morteiro en granito para machucar alimentos. A isto, hai que sumarlle outros elementos como fragmentos de múiños circulares ou numerosos cacharros cerámicos de cociña.

O elemento principal da sala é o forno sobreelevado. Sitúase na esquina sueste da estancia, contra os muros, cunha forma cuarto-circular. O corpo está realizado en pedra, mentres que o fogar é de material latericio, tanto ladrillos coma tégulas (fig. $5, b$ ). A cúpula sería deste mesmo material e destaca a aparición dun ladrillo cun buraco circular no centro, que interpretamos como un posible tiro ou saída de fume cara ao exterior (fig. 5, e). Ademais deste forno, atopamos no mesmo espazo un fogar a rentes do chan ao lado do muro sur da cociña. Está realizado cunha base de tégulas e rodeado con ladrillos fincados, agás no lado que dá contra o muro (fig. $5, \mathrm{~b}$ ). Neste lado aparecen dous grandes perpiaños pétreos que separan o fogar do muro e que posiblemente estarían sustentando a cuberta-cheminea. O forno e o fogar desta culina serían coetáneos. Entre o forno e o fogar apareceu unha pedra granítica rebaixada que, polas marcas que presenta, interpretamos como morteiro, relacionado con algunha actividade como a moenda ou o machucado de alimentos.

Por debaixo desta última ocupación, neste mesmo espazo atopamos niveis anteriores. Ademais de diversos muros, apareceu tamén un fogar de tégulas contra un deles, polo que é posible que tamén fose unha cociña en momentos anteriores.

A cociña localizouse no ano 2014, cando apareceron os ladrillos do forno, pero non foi ata as campañas de 2015 e de 2016 cando se escavou na súa totalidade. Presentaba unha gran potencia estratigráfica, con sucesivas capas negras 
con restos de queimado, que relacionamos coas actividades de limpeza do forno e do fogar. O pavimento é de terra pisada e superpoñíanse capas de terra ás capas negras descritas anteriormente. Ademais do morteiro e dos muíños, nesta estancia destaca a abundancia de grandes cazolas e pratos que poderían servir para cociñar os alimentos no forno e/ou no fogar (fig. 5, f). Algunhas das cazolas presentan perfís compatibles co seu uso como «tapadeiras»-similares aos clibani romanos- para elaborar o pan (fig. 5, g). Ademais, aparecen numerosas fusaiolas e pesas de tear asociados á cociña, polo que podemos supoñer que neste espazo tamén se realizaban actividades relacionadas co téxtil.

A terraza da Atalaia foi intensamente ocupada desde o cambio de era, pero a construción da rúa central empedrada e das domus corresponderían coa fase

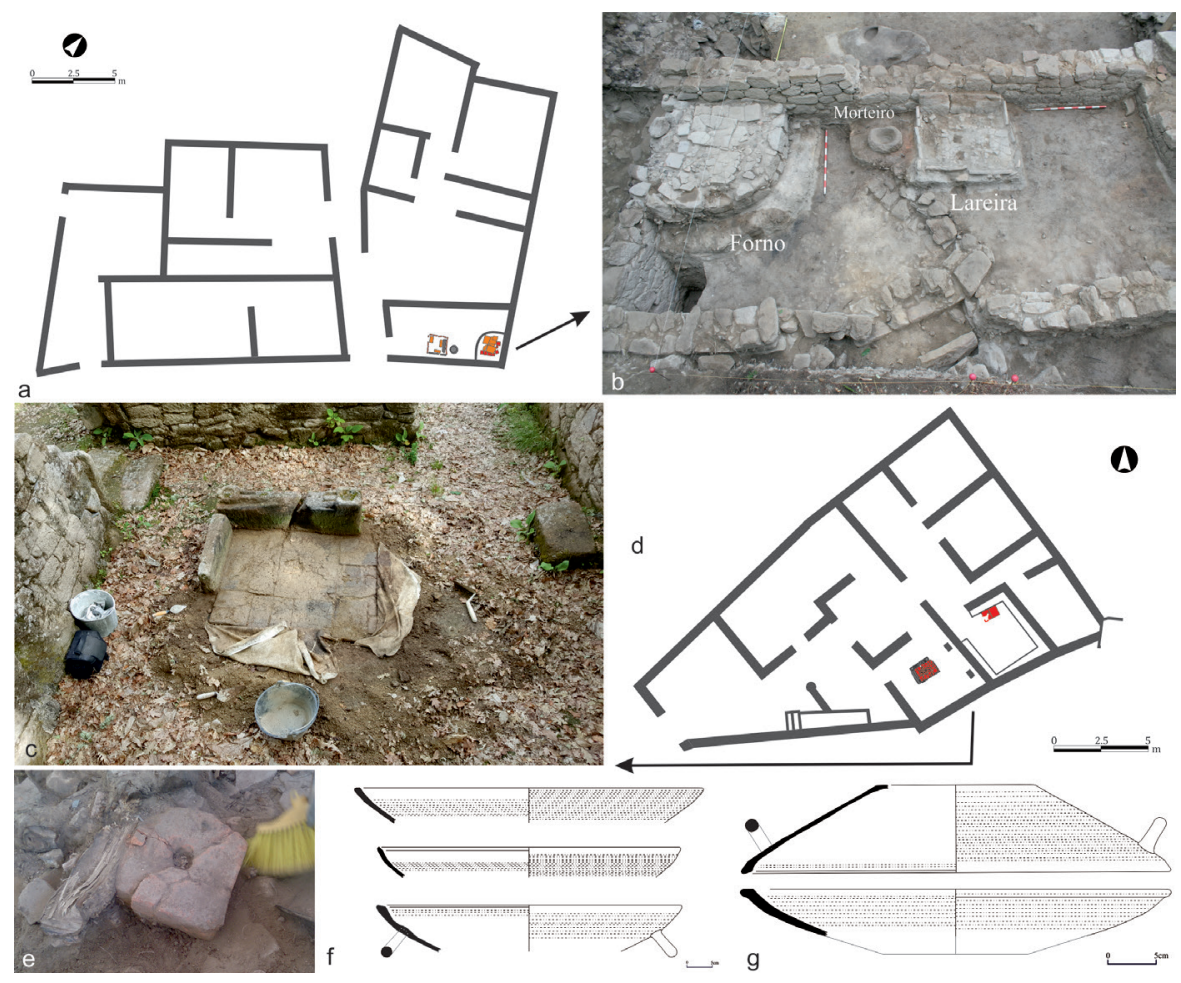

Fig. 5. a-b: Planimetría e cociña da domus do Hexáscele (elaboración propia); c-d: cociña da domus da Roseta (elaboración propia). e: tiro do forno da cociña da domus do Hexáscele (foto dos autores). f: cazolas-tapadeira para cocer o pan (debuxos dos autores). g: hipótese de uso das cazolas-tapadeira $^{50}$.

\footnotetext{
${ }^{50}$ A partir de Alba A. Rodríguez NóvoA, Yacimientos castrexos de la cuenca del Miño: análisis de la cerámica indígena, tese de doutoramento, Santiago de Compostela, Universidade de Santiago de Compostela, 2019.
} 
Flavia. Esta fase dátase desde finais do século I ata finais do s. II-inicios do s. III, dada a importante presenza de TSH entre o conxunto cerámico recuperado.

\subsection{Armea-Domus da Roseta (fig. 5, c-d)}

A cociña da domus da Roseta localízase nun espazo interno, en contacto case directo co patio de entrada á casa. A diferenza da domus do Hexáscele, esta culina non ten contacto co patio interior, onde si localizamos outro tipo de estancias, algunha delas posiblemente asociada á cociña (fig. 5, d).

A cociña presenta dous accesos, un desde o patio e outro que comunica cunha estancia previa ao corredor que artella a parte interna e baixa da casa, xunto ao atrio (fig. 5, d). A lareira sitúase no centro da estancia, e é ata o de agora, xunto co fogar de Pazo Lomas-Lugo, os únicos exemplos coñecidos con esta disposición en Galicia, semellante porén á identificada na vila xixonesa de Veranes. ${ }^{51}$ Esta lareira cuadrangular está delimitada nos seus lados norte e oeste por pedras de granito, deixando libres a parte sur e leste, por onde se procedería a manipular os alimentos e a controlar o lume. O perpiaño norte (hoxe fragmentado) presenta na parte superior unha basta decoración e dous apoios para os postes de madeira que soportarían o tiro do fogar e no cal se poderían sustentar as estruturas de soporte do pote. No lateral leste da estancia hai dous perpiaños graníticos rectangulares e aliñados entre si que identificamos como apoios dun andel para gardar alimentos ou incluso como soporte dunha artesa.

Desgraciadamente non coñecemos con seguridade os usos das habitacións situadas ao norte e ao oeste, aquelas coas que comunica esta cociña dado que foron escavadas nos anos cincuenta por F. Conde-Valvís. Conformarían coa cociña un ambiente doméstico, probablemente relacionado coa propia culina. Sen comunicación directa coa cociña, aínda que lindando con ela polo leste, atopamos unha estancia con poste central e cun banco corrido de obra que podería servir como soporte de estantes. Contra o banco e o muro norte identificouse unha zona de combustión sinalada por dúas tellas volteadas, probablemente para quentar a habitación. Nesta estancia recolléronse gran cantidade de pondus cerámicos, o que indicaría unha área de manufactura téxtil, tamén de almacenaxe e seguramente con outras funcións que polo de agora descoñecemos. Nesta casa, a área de moenda atópase na zona do patio, protexida polo corredor elevado do segundo piso, onde se atopou un gran morteiro de granito e un muíño in situ de grandes dimensións.

\footnotetext{
${ }^{51}$ Carmen Fernández OchoA, Fernando Gil Sendino e Almudena Orejas SACo del Valle, "La villa romana de Veranes. El complejo rural tardorromano y propuesta de estudio del territorio", Archivo Español de Arqueología, vol. 77, núm. 189-190 (2004), páxs. 197-219.
} 
A gran diferenza entre os espazos culinarios das dúas domus de Armea é que a do Hexáscele concentra nun só espazo varias actividades, mentres que na domus da Roseta, as citadas actividades -moenda, téxtil, almacenaxe- atópanse delimitadas por compartimentos, en ocasións en contacto directo entre eles e noutras non, pero sempre asociados na parte baixa-central da vivenda.

\subsection{Vila romana de Riocaldo (Aquis Originis?) (fig. 6)}

A villa romana de Riocaldo localízase a carón do río Caldo e moi preto das aldeas de Torneiros e de Baños (Lobios, Ourense) (fig. 1). Sitúase nunha plataforma sobreelevada sobre o río e ao pé da Vía XVIII do itinerario de Antonino. Actualmente vénse identificando o xacemento coa mansio de Aquis Originis, ${ }^{52}$ descartando a hipótese anterior que a situaba no lugar dos nacentes de augas termais e que ocupaba a antiga casa de baños e hoxe o hotel balneario. Descuberto en 1988, o xacemento foi escavado entre 1989 e 1996, descubríndose parte da pars urbana da villa, en concreto un edificio termal e outro próximo identificado como unha culina dividida en tres ou catro estancias das cales soamente se atopan totalmente escavadas dúas (fig. 6). Das escavadas por completo, a de menor tamaño $\left(10,35 \mathrm{~m}^{2}\right)$ ten morfoloxía en $\mathrm{P}$ e acceso mediante un van localizado no sueste. No centro, presenta unha lareira ou fogar circular sobreelevado. Está separado do pavimento por unha ampla concavidade de seguridade; con este espazo, o fogar ocuparía unha área circular dun metro de diámetro. Este habitáculo da cociña contiña potentes camadas de cinsas froito da limpeza do fogar. ${ }^{53}$

A estancia de maior tamaño $\left(15 \mathrm{~m}^{2}\right)$ ten planta rectangular e sitúase ao norte da anterior sen comunicación directa entre elas. Igual que ocorría na estancia anterior, documentáronse importantes camadas de cinsas por todo o chan. No ángulo noroeste localízase un forno de planta rectangular de 1,55 x 1,70/1,80 m. A boca de alimentación situábase ao sur, onde se localizaban as capas de queimado máis potentes. O forno conserva o lar e o inicio da cámara abovedada, cunha grella de tegulas dispostas en posición invertida sobre unha capa de area e, baixo desta, unha capa de lousas, destinadas a impedir a perda de calor. Nesta estancia recuperáronse varios fragmentos de muíños manuais e un molde de barro de panadeiro ou reposteiro, cunha escena mitolóxica en relevo negativo. ${ }^{54} \mathrm{~A}$ este espazo accédese por un van situado ao norte e que comunica cunha área aberta

\footnotetext{
${ }^{52}$ Manuel Xusto Rodríguez, “A villa romana de Riocaldo: estado da cuestión”, Brigantium, 12 (2000), páxs. 228-232.

53 Xusto Rodríguez, “A villa romana de Riocaldo...”, páx. 235.

${ }^{54}$ Xusto Rodríguez, “A villa romana de Riocaldo...”, páx. 238.
} 
porticada. Faltaría, polo tanto, coñecer a funcionalidade dos dous espazos existentes cara ao leste que sen dúbidas estaban relacionados co espazo culinario.

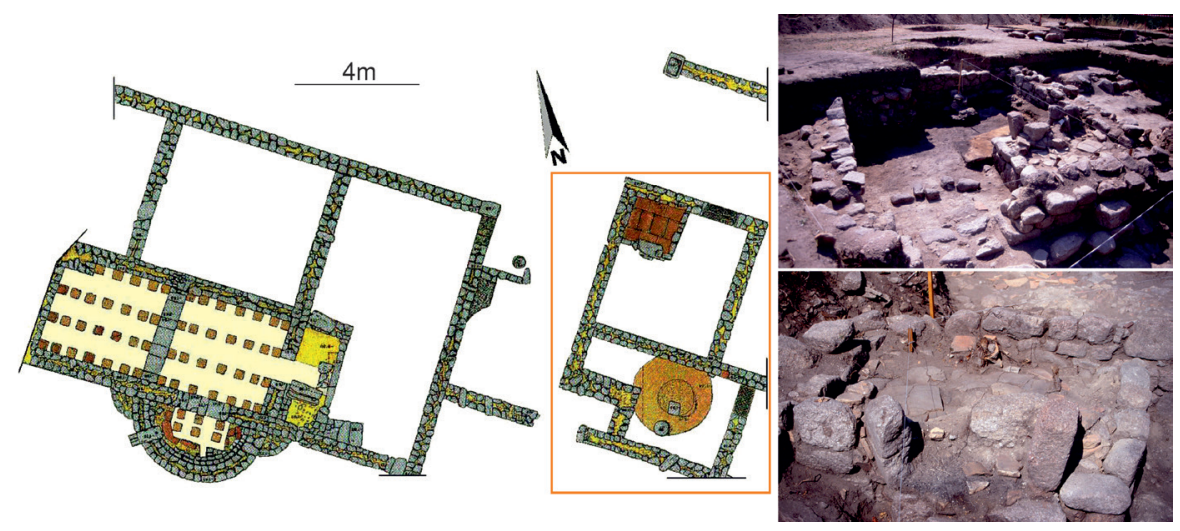

Fig. 6. Planimetría da villa de Riocaldo ${ }^{55} \mathrm{e}$ foto do espazo do forno e en detalle do forno (fotos de F. Pérez Losada).

\subsection{Villa romana de Toralla-edificio principal (fig. 7, a-c)}

Na villa romana de Toralla documentáronse dúas cociñas, unha delas incluída dentro da estrutura do edificio principal (completamente escavado), e a outra formando parte doutra edificación (edificio secundario ou edificio 3) localizada ao suroeste do anterior edificio e só parcialmente escavada (fig. 7). A cociña do edificio principal de Toralla forma parte dunha estrutura de planta rectangular alongada, organizada a partir dun corredor lonxitudinal (P) e un compartimento en nove estancias (denominadas H, I, J, K, L, M, N, O e Q). As estancias O, N e Q corresponderíanse con cubicula, a gran estancia L cun salón de prestixio (oecus), mentres que a estancia $\mathrm{K}$ e a $\mathrm{M}$ se corresponderían cunha área termal caracterizada por un hipocausto $(\mathrm{K})$ con dúas bañeiras e un chan de mosaico á que se accedería pola estancia $\mathrm{M}$, onde se localiza unha gran piscina fría; e establécese así un circuíto de tipo lineal retrógrado (caldarium, tepidarium, frigidarium). O terceiro sector da vivenda aparece conformado por estancias funcionais e de servizo. Son tres espazos situados no extremo occidental do edificio e soamente accesibles desde o exterior, carecendo dunha comunicación directa coa parte residencial e lúdica da vila (fig. 7). O espazo J, ao que se accede mediante

\footnotetext{
${ }^{55}$ Fermín Pérez Losada a partir de Manuel Xusto Rodríguez, "A villa romana de Riocaldo: estado da cuestión", Brigantium, 12 (2000), páxs. 227-246.
} 
un van na fachada sur do edificio, alberga a boca do forno do espazo termal, funcionando tamén como zona de almacenaxe para combustible e outro tipo de produtos. Desde a estancia do praefurnium accédese, mediante dous chanzos, ao espazo H, identificado coa culina da casa. Por último, a estancia I, paralela á anterior e de dimensións lixeiramente superiores, interprétase como unha despensa (cella penaria) dado o elevado número de cerámica de almacenaxe recuperado no seu interior e a presenza dos apoios de posibles estruturas de madeira (estantes?) contra os muros laterais.

A análise pormenorizada desta culina non se pode disociar dos seus espazos anexos xa que, como indicamos anteriormente, conforman o espazo funcional e de servizo. A cociña sitúase no esquinal noroeste da vivenda e é accesible soamente desde o almacén do praefurnium mediante unha escaleira de obra que salva o desnivel entre ambas as estancias. Xunto á estancia contigua (almacén), conforman o espazo funcional da casa. A culina ten planta rectangular con tres fogares de diferente morfoloxía e cronoloxía (fig. 7, a). Nun primeiro momento constrúese un fogar no esquinal nordeste, de forma elipsoidal con ladrillos bessalis fincados e unha laxe de granito nun dos seus laterais. A superficie interior construíuse mediante a deposición de arxila e detectouse unha reparación na súa parte central mediante a incorporación á prancha de tres ladrillos (fig. 7, b).

Nunha segunda fase parecen construírse dous novos fogares e amortízase o anterior. Un deles, situado no esquinal suroeste da cociña e xusto ao lado da porta de acceso presenta dúbidas en canto á súa función. Tres pedras de granito delimitan un espazo irregular de queimado cuxa superficie ten restos de arxila rubefactada. A súa forma e estrutura afástase dos restantes fogares da casa e, aínda que a súa función para facer lume queda fóra de toda dúbida, non parece claro que se utilizase para a cocción de alimentos (fig. 7, a). O seu nivel de uso parece coincidir co da última fase da cociña, coetáneo co terceiro fogar, polo que parece estraño que coincidan no tempo dous fogares no mesmo espazo. O terceiro fogar presenta unha forma rectangular delimitada por ladrillos e laxes de granito fincadas no pavimento mentres que a prancha se constrúe con catro ladrillos de tipo lydios (fig. 7, c). Localízase case en fronte do primeiro e máis antigo fogar sen espazo de traballo de estar o primeiro aínda activo, o que indica que xa se encontraba amortizado. Entre o fogar e a parede oeste da cociña constrúese un muro baixo mediante ladrillos reutilizados (un deles é de entalle) e cachotaría de granito, servindo de apoio ao tiro/cheminea do fogar, que apoiaría na parte frontal en dúas columnas de granito das que se recuperaron os seus baseamentos posiblemente in situ (fig. 7c). Neste caso, non se observan reparacións, aínda que a parte central do fogar presenta intensas marcas de lume ata o punto de que un dos ladrillos está case totalmente destruído. O pavimento da cociña é de terra pisada depositada sobre os recheos da construción a base de area de praia. As 
continuas limpezas dos fogares deixaron sucesivos niveis de cinsas no pavimento onde se recuperou unha gran cantidade de material, especialmente cerámico. A pesar de que a vaixela fina aquí é pouco común, os escasos fragmentos de ARS e TSHT apuntan a unha cronoloxía de abandono do espazo a finais do século IV. ${ }^{56}$ Máis difícil é precisar a data de construción, que se pode sinalar o inicio do século IV como o máis probable segundo o estudo da totalidade do material cerámico datable recuperado na escavación do edificio principal. ${ }^{57}$

\subsection{Villa de Toralla-edificio secundario (fig. 7, d-f)}

A segunda das cociñas da villa de Toralla forma parte dun edificio rectangular enfrontado coa fachada sur (a área servil) do edificio principal. Esta edificación foi parcialmente escavada durante as campañas de 2002, 2003 e 2007, e quedou soamente visible o seu esquinal oeste, onde se localizan dúas estancias en batería de dimensións descoñecidas ás que se accede desde a área aberta entre ambos os edificios. Unha delas identifícase como unha cociña, xa que conta cun fogar e outras evidencias.

Nunha das estancias, situada no esquinal noroeste, documentouse un magnífico fogar de forma máis ou menos rectangular, delimitado por ladrillos e laxes de granito fincadas e prancha de ladrillos, sobre o que se construíu un novo fogar máis pequeno e cadrado aproveitando un dos lados do anterior. Este segundo fogar delimítase con ladrillos bessalis, lidios e unha laxe de granito, mentres que a prancha se constrúe con ladrillos. Documéntase unha terceira fase caracterizada por unha reparación na zona central mediante a incorporación de dous novos ladrillos. Sobre o fogar recuperáronse fragmentos dunha cadea de ferro que serviría para suspender un caldeiro/pote sobre o lume do fogar. O pavimento da cociña é de terra pisada.

O espazo tamén se utilizou para actividades téxtiles como o proba a presenza de dous catillus reaproveitados para suxeitar a estrutura dun tear que estaría apoiado contra o muro leste. Xunto aos apoios recuperáronse varios pondus cerámicos tronco-piramidais e laxes de lousa perforadas que tamén funcionarían como pesos. Na estancia contigua, da que apenas se escavou a parte da entrada, recuperouse un gran morteiro de granito utilizado seguramente para a transformación de alimentos e, por tanto, directamente ligado á cociña anexa.

\footnotetext{
${ }^{56}$ Adolfo FERNÁNDEZ FERNÁNDEZ, El comercio tardoantiguo (ss. IV-VII) en el noroeste peninsular a través del registro cerámico de la ría de Vigo, Oxford, Archaeopress, 2014 (Roman and late antique Mediterranean pottery, 5).

57 Fernández Fernández, El comercio tardoantiguo..., páxs. 15-30.
} 

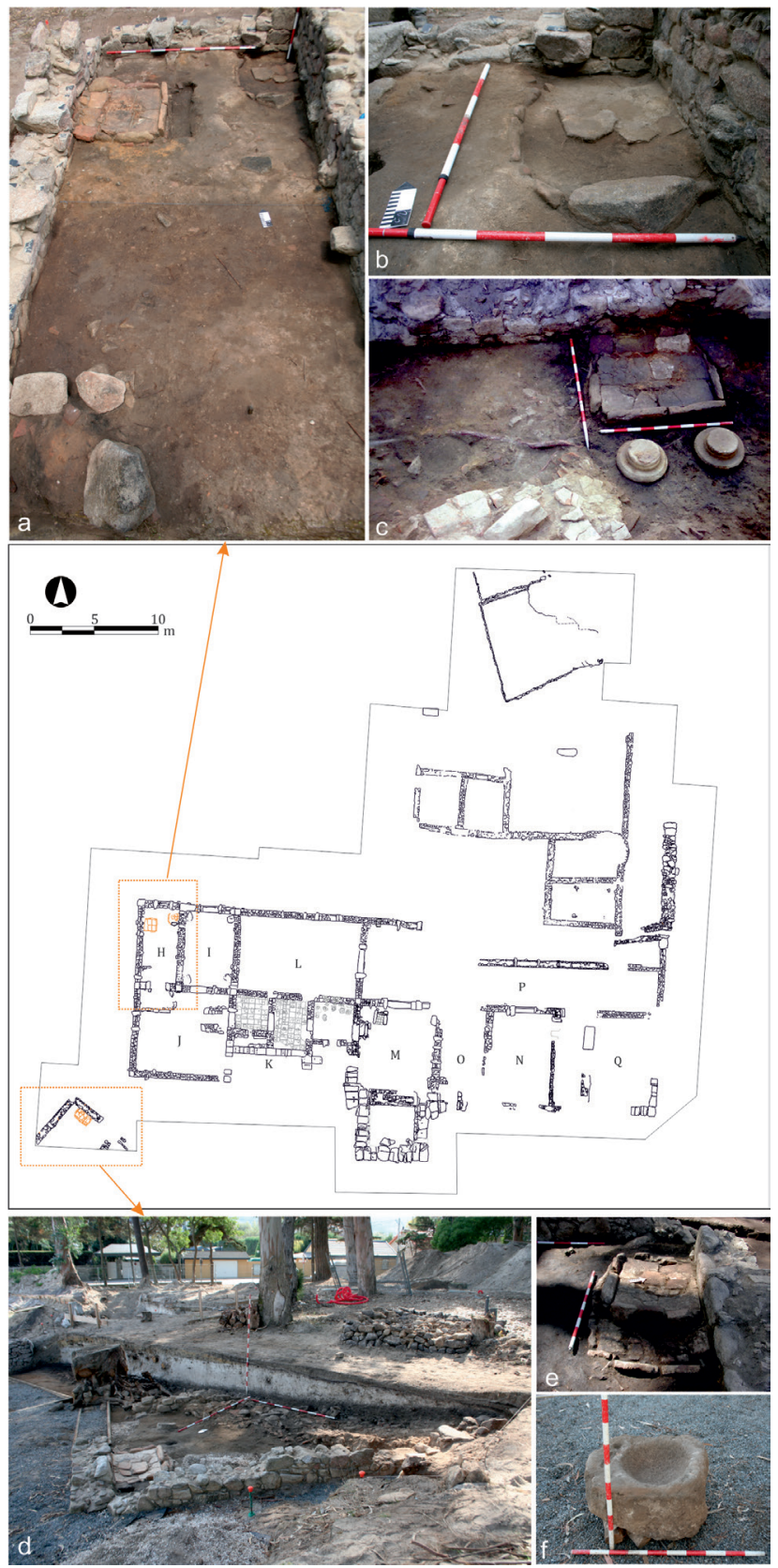

Fig. 7. No centro, planimetría da villa (elaboración propia); a-c: fogares da cociña do Edificio Principal (fotos dos autores); d-f: cociña do Edificio Secundario, lareira e morteiro (fotos dos autores). 
Esta zona do edificio 3 mantívose en uso, polo menos, ata mediados do século v. ${ }^{58} \mathrm{~A}$ pesar das sucesivas fases documentadas no fogar, non parece que a cociña e o resto do edificio exhumado tivese unha longa vida útil, e puido construírse nun momento próximo ao abandono do edificio principal (segunda metade do s. IV?).

\subsection{Rúa Nova-Lugo (fig. 8 a-d)}

Os soares núm. 68 e 70 da rúa Nova (Lugo) atópanse no interior do recinto amurallado da cidade. A intervención arqueolóxica consistiu nunha escavación en área na que apareceron numerosos restos xa desde os niveis superiores, con datacións que ían desde a época contemporánea á época romana. Entre os restos atribuíbles á fase romana documentáronse diversas estruturas e estancias, aínda que bastante arrasadas. Estes restos interpretáronse como unha domus alto imperial con niveis de reocupación que chegaban ata o século IV. O edificio baixo imperial construíuse sobre os restos dun edificio anterior, aproveitando e anulando antigos muros, e sobre fosas de extracción de arxila, así como algunha posible pía, que apuntan a un uso artesanal, que, segundo a súa localización, e os restos materiais localizados, apuntan a un taller de olaría, posiblemente relacionado cos fornos localizados anos atrás nas intervencións realizadas nos soares adxacentes.

As estruturas localizadas no sector oeste (fig. 8, a) correspóndense cun complexo doméstico formado por un muro mestre que atravesaba os soares de leste a oeste. A partir deste, saen muros perpendiculares para conformar varias estancias ás que se accede desde o norte, ata onde se desenvolvería o resto da casa. Estas habitacións ao norte do muro terían unha funcionalidade doméstica e entre elas destacan dúas estancias pavimentadas con opus signinum (posibles almacéns?) e unha cociña. Ao sur das estancias sitúanse restos de pouca entidade identificados como unha zona residual e exterior da casa.

A cociña sería a primeira das habitacións polo lado suroeste (fig. 7, a-b). Ten unhas medidas de $3 \times 4,40 \mathrm{~m}$, aínda que non foi exhumada na súa totalidade. A súa definición como espazo culinario débese á aparición dun fogar contra un muro. O fogar estaba conformado por unha pedra plana, disposta nun buraco escavado para a súa colocación no pavimento da estancia, cunhas pequenas lousas a modo de calzo para a súa nivelación (fig. 7, c).

Ademais, a estancia conta cun muíño circular in situ, colocado sobre o pavimento de arxila compactada cunhas pedras dispostas como base ou plataforma

58 Fernández FernÁndez, El comercio tardoantiguo..., páxs. 15-30. 
e, xunto a estas, unhas lousas fincadas verticalmente (fig. 7, d). Os arqueólogos propoñen que servisen para recoller o produto da moenda. O pavimento era de arxila compactada, existindo no nivel de uso evidencias de carbonizacións que poden estar relacionados co uso e coa limpeza do fogar.

Os diferentes depósitos relacionados con este espazo presentaban abundantes restos de carbonizacións, así como fragmentos de cerámica de cociña e de almacenaxe, que non aparecen no resto da escavación. Algúns destes fragmentos presentaban restos de concrecións que se puideron formar ao queimarse tras ser expostos ao lume.

Estas estancias funcionais formarían parte dunha gran domus baixo imperial que se estende máis alá do soar intervido. Escavacións próximas exhumaron novas estancias da vivenda que parece artellarse ao redor dun gran corredor ao que se abren as habitacións, entre elas as analizadas aquí como zona de cociña. Ao outro lado da rúa de Bolaño Rivadeneira, no soar núm. 72, aparecen restos que se poderían corresponder coa continuidade do edificio anterior. Un dos espazos podería ser a continuación do espazo da cociña dos soares 68-70, xa que o seu chan posuía as mesmas capas documentadas na cociña. No entanto, a distancia entre elas non fai posible asegurar que se trate do mesmo espazo.

\subsection{Rúa do Xeral Tella, esquina rúa de Ribadeo-Lugo (fig. 8, e-h)}

No ano 1992 escavouse o soar correspondente á esquina das rúas do Xeral Tella (actual Puro Cora) e a rúa de Ribadeo, dirixida polos arqueólogos S. Ferrer e E. González. A extensión da zona escavada ascendeu a $420 \mathrm{~m}^{2}$. Os restos localizados identificáronse como un espazo urbano relacionado co ámbito doméstico que segue a orientación (NL-SO) e o trazado ortogonal da cidade. Localizáronse tres edificios (coñecidos como A, B e C) separados entre si por estreitos corredores (fig. 8, e).

O denominado edificio A, situado no leste do soar, aparece separado do edificio central, ou edificio B, por un estreito corredor de $90 \mathrm{~cm}$. Del coñecemos dúas habitacións parcialmente escavadas que continúan baixo o perfil sueste da escavación, onde se situarían as portas de acceso (fig. 8, f-g). A habitación A1 deste primeiro edificio presenta unha planta cadrada/rectangular delimitada por muros construídos en lousa e arxila amarela. Na esquina leste, atopouse unha lareira delimitada por tégulas disposta verticalmente e prancha do mesmo material construtivo, mentres que a habitación está pavimentada con lousas que soamente se conservaron nalgunhas zonas. Como xa vimos en casos anteriores, documentouse unha importante capa de carbonización (fig. 8, h). 
A habitación A2 aparece xunto á anterior, delimitada por dous muros de lousa e de menor anchura cós da estancia A1. No esquinal oeste localizouse unha construción en cuarto de círculo, levantada co mesmo material, salvo por algunha tegula conservada na cimentación (fig. 8, f-g). A pesar de conservar soamente a súa caixa, esta estrutura debe identificarse cun forno como demostraría o feito de que o chan desta habitación tamén contaba con abundantes restos de carbonizacións. A presenza de bases fainos pensar que existían estantes, polo que esta estancia puido funcionar tamén como almacén relacionado directamente coa anterior habitación.

As capas de nivelación do terreo para a construción do edificio A dátanse ao redor do século I e inicios do século II. Os materiais procedentes dos estratos do pavimento desta estrutura sinalan como terminus ante quem, unha data sobre finais do século III d. C., pola presenza de TSH coa forma 37, con tipos formais e decorativos próximos á TSHT (sen que chegue a aparecer esta produción), xunto á aparición dunha fíbula con esmalte do tipo II de Exner, moi frecuente na rexión renana e na Gallia na segunda metade do século II e século III. Tras o
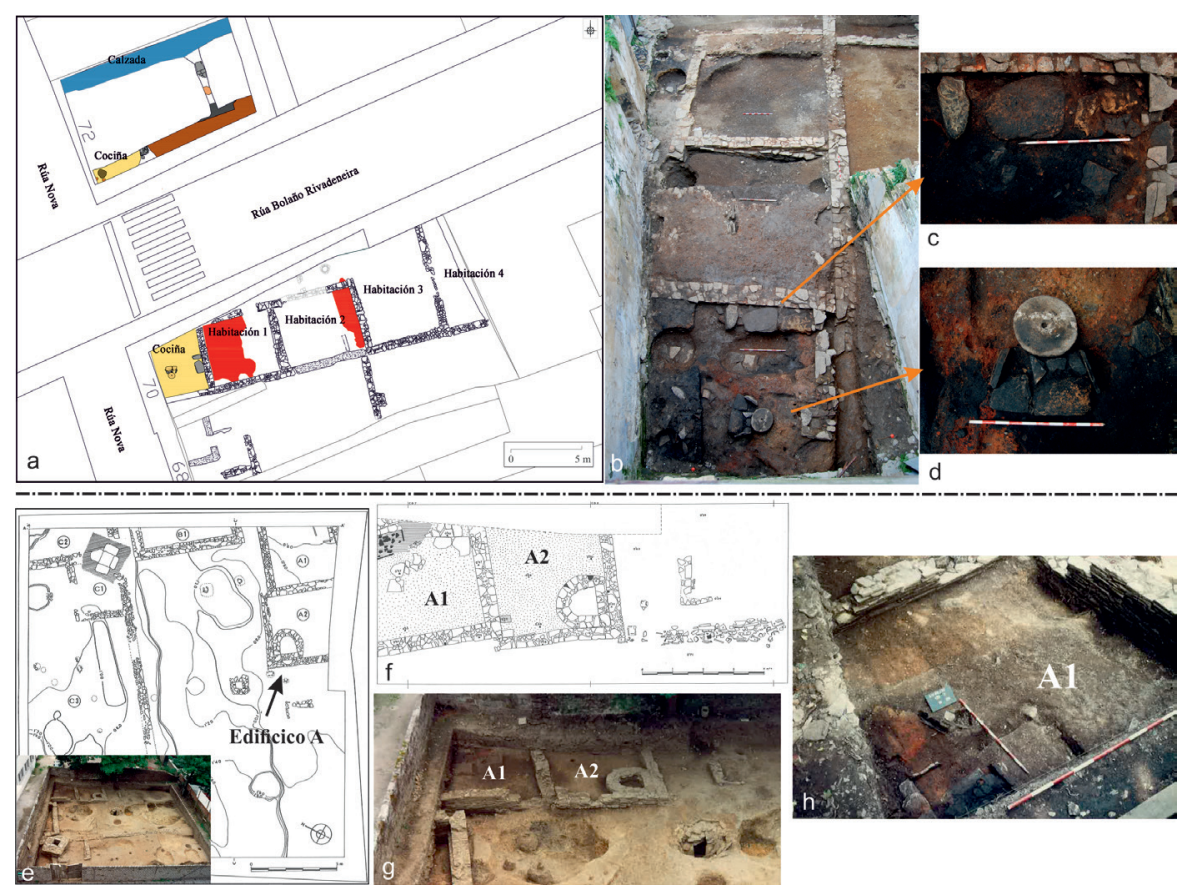

Fig. 8. Casos de estudio de Lugo. a-d: planimetría e imaxes da cociña de rúa Nova (planta ou plano e fotos dos autores); e-h: planimetría e imaxes dos espazos domésticos identificados na rúa Xeral Tella (Cortesía de E. González Fernández e S. Ferrer Sierra). 
seu abandono, esta zona non foi reocupada, debido posiblemente a que quedaba fóra do recinto amurallado da cidade tras a construción deste e mesmo quedaría a unha distancia considerable.

\section{ANÁlise E INTERPRETACIÓN}

O catálogo de espazos culinarios e os sete casos de estudo achégannos importantes datos sobre a realidade romana destas áreas domésticas na Gallaecia. Os datos do catálogo son escasos pero ilustrativos, e unidos á análise máis profunda dos casos, móstrannos a relación da cociña con outros espazos domésticos, a súa distribución interna, os elementos que a conforman e as actividades desenvolvidas no seu interior. Os espazos culinarios estudados en profundidade son os que verdadeiramente abarcan a totalidade do espectro cronolóxico e espacial ao incluír ambientes domésticos urbanos (Lugo), urbanos rurais de tradición indíxena (Armea), villae costeiras (Toralla) e unha mansio da Galicia meridional (Riocaldo), con cronoloxías que van desde o cambio de era ata o s. v d. C.

\subsection{Sobre a súa localización e relación cos demais espazos}

Soamente nalgúns exemplos puidemos visualizar a relación dos espazos culinarios coas demais estancias domésticas. Nestes casos, o máis habitual é que ocupen unha zona concreta da vivenda, normalmente un extremo afastado das habitacións/dormitorios e dos habitáculos de reunión (salóns). Na domus do Hexáscele-Armea (24), en Santomé (22), en Lugo-rúa Nova (14), en Lugo-Xeral Tella (16) ou en Agro de Nogueira (8) artéllanse a partir dun patio ou corredor(es) que separan os diferentes ambientes das vivendas. Nestes casos, a estancia propiamente da cociña - onde se localiza o(s) fogar(es)-, acompáñase doutros espazos intercomunicados onde se desenvolven tarefas relacionadas coa almacenaxe e coa transformación de alimentos (vid. infra). Cando existe un complexo termal, como no edificio principal de Toralla (36), en Cambre (6) ou en Noville (1), a cociña sitúase contigua, conformando coa zona do praefurnium e almacéns os espazos funcionais da vivenda. No caso de Toralla, a pesar de estar pegado á zona de habitacións, non existe comunicación directa entre ambos os ambientes, tendo que acceder á zona funcional desde o exterior. Esta situación podería repetirse en Noville, aínda que neste caso, debido á área de intervención, non o podemos asegurar. No caso de Aquis Originis (30), este espazo aparece separado fisicamente, pero próximo á zona termal. Aquí, todo indica que as estancias de cociña e de moenda conforman unha unidade independente á que se accede desde unha área aberta. En Armea-Monte do Señoriño (25), a cociña e outras dependencias anexas sitúanse na parte máis elevada da vivenda e probablemente separadas da 
zona habitacional por un patio aberto. Esta separación física entre ambientes culinario e/ou termal, ou a súa localización nun extremo dela, parece algo habitual. Seguramente esta disociación dos ambientes, e das persoas (persoal de servizo vs. dominus e familia), busca protexer unha parte da vivenda dun posible lume ocasionado na zona da cociña e dos praefurnia das áreas termais. Reprodúcese, polo tanto, na maior parte dos casos a concepción vitrubiana (cap. IX) destes espazos, que sitúa as áreas termais a carón das cociñas.

\subsection{Sobre a súa distribución interna e outros espazos anexos}

As cociñas escavadas por completo son a miúdo espazos reducidos en comparación con outras habitacións das vivendas. A cociña (culina) propiamente dita é onde se localizan o fogar e/ou o forno utilizado para cocer alimentos. En ningún dos casos recompilados se detectou unha división interna e física da cociña, aínda que si parecen existir diferentes áreas funcionais no seu interior. No entanto, puidemos comprobar que habitualmente esta estancia está acompañada por outras anexas intercomunicadas entre si ou accesibles desde unha zona común (patio, perístilo, corredor, área aberta etc.), conformando a zona funcional, produtiva e de servizo da vivenda. Na maioría dos casos onde documentamos a presenza dun forno de pan, este sitúase nunha estancia anexa pero con comunicación directa entre elas ou a partir dun espazo común (corredor, patio ou a partir doutra estancia). Son os casos de Noville (1), Caldoval (2), Agro de Nogueira (8), Aquis Originis (30), Lugo-Xeral Tella (16), Bueu-villa? (34) ou na última fase da mansio de Aquis Querquenis (29). A excepción é a cociña da domus do Hexasquel-Armea, onde nun mesmo espazo se localizan fogar(es) e forno de pan. Non se trata dun caso único no noroeste, xa que na próxima domus do Chao San Martín (Grandas de Salime) aparece unha culina semellante á de Armea, onde fogar e forno de pan comparten un mesmo espazo ao carón da latrina e das termas da vivenda. ${ }^{59}$ Tamén a zona de moenda pode aparecer separada da cociña, pero sempre no seu contorno inmediato, como sucede na mansio de Aquis Querquenis (29), na domus do Mitreo-Lugo (15) ou no edificio secundario da villa de Toralla (37). Nestes casos, trátase de grandes estruturas de moenda ou de machucado (morteiros), aínda que tamén poden aparecer muíños máis pequenos na propia cociña. Con todo, o máis habitual, como observamos nos casos de estudo, é que as actividades de moenda se desenvolvan na propia cociña ou, cando existe, na propia estancia do forno.

\footnotetext{
59 Ángel Villa Valdés, Rubén Montes LóPez e Olga Gago Muñoz, Domvs. Una casa romana en el castro de Chao Samartín. Exposición temporal y ciclo de conferencias, Xixón, Consellería de Educación e Cultura, 2006; Rubén Montes LóPEZ e Ángel Villa VAldÉs, "Una domus altoimperial en el castro de Chao Samartín (Asturias): quién, cómo y porqué”, Férvedes, 8 (2015), páxs. 277-284.
} 
A cociña e/ou forno son acompañados por outras estancias destinadas probablemente á almacenaxe de combustible, útiles e todo tipo de alimentos. En canto a estas, son difíciles de identificar, xa que en moitos casos non contan con elementos singulares que nos leven a interpretar satisfactoriamente estes espazos como lugares de almacenaxe ligados ao resto de estancias culinarias. No entanto, contamos con posibles exemplos destes espazos como nos casos (entre outros) da estancia I do edificio principal da villa de Toralla (36) ou na domus da Roseta-Armea (23), caracterizados pola presenza de restos de apoios para andeis ou importante presenza de cerámicas de almacenaxe. Non podemos descartar que sobre estes apoios -tanto en Armea coma en Toralla- se situasen artefactos tan importantes como as artesas para amasar o pan, pero tamén estruturas para gardar a fariña ou o propio pan unha vez cocido.

Algo común para as cociñas romanas de Galicia son os pavimentos, salvo algúns casos, realizados en terra pisada, onde se acumulan sucesivas capas de cinsas froito das limpezas dos fogares e/ou dos fornos. De novo, contamos con excepcións, como a estancia do forno da villa de Agro de Nogueira (8), cun pavimento a base dun basto opus signinum que se estende tamén pola estancia anexa, ou no caso da cociña do Xeral Tella-Lugo (16), que conta cun chan de lousas de xisto.

\subsection{Os elementos que a conforman}

Sen ningunha dúbida, o elemento principal da cociña é o fogar. Nos casos galegos, estes fogares sitúanse pegados ás paredes e a rentes do chan. Porén, contamos con catro casos diferentes: a domus da Roseta-Armea (23) e en Pazo Lomas-Lugo (13), onde o fogar de planta cadrada se sitúa no centro da cociña; na domus do Mitreo-Lugo (15), onde contamos cun fogar rectangular de obra sobreelevado aproveitando o esquinal da culina; e en Aquis Originis (30), onde un «infrecuente» fogar circular sobreelevado ocupa a zona central da cociña. Nestes dous últimos casos, descartamos que sexan fornos abovedados polo que se tratan, ata o momento, dos únicos fogares romanos na actual Galicia non construídos a rentes do chan, algo por outra parte habitual en cociñas mediterráneas como as máis que coñecidas de Pompeia ou Herculano ${ }^{60}$.

Como sinalamos, os fogares anéxanse ás paredes da cociña, especialmente aproveitando esquinais, facilitando así o tiro e a saída do fume. Porén, habitualmente non se dispoñen directamente contra os muros, senón que se deixa un espazo entre a prancha do fogar e a parede, ocupado xeralmente por unha estru-

${ }^{60}$ John R. Clarke, The House of Roman Italy, 100 B. C. - A. C., University of California Press, 1991. 
tura pétrea ou construída con material latericio que serve de apoio para posibles cubertas ou estrutura(s) existente(s) sobre o propio fogar. Na maioría dos casos contarían con algún tipo de «cúpula-cheminea»-hoxe perdida- para canalizar a saída de fumes e que se podería apoiar en postes de madeira -como na domus da Roseta-Armea (23) (fig. 5, c)- ou mesmo en columnas pétreas, como no caso do fogar do edificio principal de Toralla (fig. 7, c), onde se recuperaron dúas bases de granito in situ. No caso de que non existisen estas estruturas, os fumes evacuaríanse polo propio tellado e por pequenas fiestras.

As plantas máis habituais dos fogares son as cadradas e rectangulares, aínda que nalgunhas ocasións poden presentar plantas semicirculares, como nas cociñas da villa de Toralla (36 e 37) ou en Pazo Lomas-Lugo (13). Resulta paradigmático que, cando estas lareiras se amortizan, sobre elas se constrúen outras, nesta ocasión cadradas. Delimítanse habitualmente mediante ladrillos fincados nos pavimentos térreos combinados con laxes de pedra local (granito ou xisto), e a zona de lume construída é mediante material latericio: ladrillos de distintos tipos e medidas, tégulas volteadas e fragmentos reaproveitados de todo tipo de material cerámico. Rara vez se utilizan para construír a prancha do fogar lousas de pedra; só documentamos este tipo de estrutura nos casos da rúa das TabernasA Coruña (5), rúa Nova-Lugo (fig. 8, c) ou no colexio das Xosefinas-Ourense (20). Non se documentaron en ningún caso estruturas anexas aos fogares, como mesados ou andeis para o apoio de obxectos e de alimentos, aínda que probablemente existiron, construídos en materiais orgánicos hoxe perdidos.

Sobre as lareiras, mediante estruturas simples de madeira combinadas con cadeas de ferro, dispúñanse cerámicas de cociña ou caldeiros de bronce e/ou ferro para cocer os alimentos. Este tipo de sistema, combinado co uso de soportes (trípodes), serían os empregados para cociñar alimentos, aínda que o máis frecuente sería colocar o recipiente cerámico ou de metal directamente sobre as pranchas do fogar e as brasas. Por desgraza, non contamos con restos materiais deste tipo de soportes, excepto varios fragmentos dunha cadea de ferro recuperada sobre o fogar do edificio secundario de Toralla (37).

Por último, cabe sinalar que, na maioría dos casos, os fogares presentan un uso prolongado que afecta a estrutura cerámica, especialmente na zona central, onde se concentraría o lume. Isto propicia que moitos se reparasen ou se superpuxesen uns sobre outros, e tamén que se amorticen na mesma cociña, substituíndo o deteriorado por outro novo localizado noutra zona da habitación. $\mathrm{O}$ caso máis claro é o do edificio principal da villa de Toralla (fig. 7 a-c), con tres fogares dispostos en diferentes partes e niveis da cociña.

Os fornos constitúen a segunda estrutura de combustión asociada ao espazo culinario. Parece que os fornos documentados estarían dedicados esencialmente (non exclusivamente) a cocer o pan. Salvo algunhas excepcións, estes fornos 
elévanse do nivel do chan algúns centímetros $(40-50 \mathrm{~cm})$ mediante un baseamento macizo de pedras (granito e/ou xisto) e terra. Os casos de Caldoval (2), Xeral Tella-Lugo (16) e Bueu-villa? (34) parecen diferentes ao presentar un baseamento oco podendo existir dúas cámaras separadas por unha grella. Trátase, nos tres casos, de exemplos incertos ao non documentarse claramente a boca de alimentación ou praefurnium.

Estes fornos sitúanse na propia cociña -xunto ao fogar-ou, o máis habitual, nunha estancia anexa aproveitando un dos esquinais, o que xera plantas de cuarto de circunferencia. Nas mansio de Aquis Originis (fig. 6) e Aquis Querquenis (fig. 4, b), os fornos localízanse nun esquinal pero presentan unha planta cadrada que é o arrinque das bóvedas circulares. Dos laterais destes potentes baseamentos xorde a bóveda que cobre a prancha interior mediante ladrillos e/ou tégulas volteadas. Nos poucos casos nos que conservamos o arrinque da bóveda, esta acostuma a ser en material latericio e é menos habitual, como no caso de Noville (fig. 2, b), que se constrúa en laxes de xisto. Na domus do Hexáscele de Armea (fig. 5, b), a cantidade de material latericio recuperado sobre a prancha do forno e o ladrillo perforado que funcionaría de respiradoiro (fig. 5, e) apuntan tamén á existencia dunha bóveda cerámica. O forno de Aquis Originis (fig. 6) é o único que conserva parte da boca do forno, e presenta linteis laterais en granito, material que tamén se utiliza para a soleira da boca neste mesmo forno e no da villa de Noville (fig. 2, b).

Nestas estancias tamén se recuperaron restos de muíños. Nelas non só se cocerían alimentos, tamén se levaría a cabo o ciclo do pan, desde a moenda ata a súa cocedura, pasando polo peneirado e o amasado. De seguro que contaba con utensilios para facilitar este proceso, como artesas para o amasado, que ata hai ben pouco formaban parte esencial do mobiliario dunha cociña tradicional galega. Por desgraza, ata o momento non contamos con restos destes útiles, seguramente por estar fabricados con materiais orgánicos (madeira), dificilmente conservables nos solos galegos.

Por último, cómpre sinalar que en Aquis Originis (30) atopouse, vinculado á estancia do forno, un probable «molde» para pan, que contaba ademais cun selo que representaba unha escena mitolóxica. ${ }^{61}$ Este tipo de moldes e de selos votivos utilizábanse para selar pans ou pasteis consumidos en festas concretas e normalmente atópanse asociados a panadarías (pistrium), aínda que non é estraño atopalos en ambientes culinarios domésticos. ${ }^{62}$ Polo momento, trátase

\footnotetext{
${ }^{61}$ Manuel Xusto RodríGuez, “A villa romana de Riocaldo: estado da cuestión”, Brigantium, 12 (2000), páxs. 227-246.

${ }^{62}$ María Eulalia Gijón Gabriel e Macarena Bustamante Álvarez, "Los sellos romanos de panadero: una aproximación a su estudio a partir de los depositados en el Museo Nacional de Arte Romano (Mérida)", Huelva en su historia, 13 (2010), páxs. 15-30; Bustamante, SAlido e GiJón, "La panificación...", páxs. 333-368.
} 
do único exemplo de selo de pan atopado non só no noroeste, senón en toda a metade norte hispánica. ${ }^{63}$

\subsection{Sobre as actividades desenvolvidas no seu interior}

Ademais da cocción de pan e outro tipo de alimentos en fogares e fornos (furnus), puidemos documentar no rexistro arqueolóxico que nas cociñas se realizaban outras tarefas. A actividade máis repetida é a moenda, incluída no ciclo da panificación e directamente relacionada coas estruturas de cocción. En practicamente todos os casos, recuperáronse nas cociñas, ou nas súas dependencias anexas, muíños completos ou parte deles (meta e/ou catillus). Nalgúns casos, como na rúa Nova, mesmo se documenta un muíño in situ cunha estrutura accesoria complexa para a moenda. Na domus do Mitreo-Lugo contamos cunha reutilización dunha estancia nobre como a área de moenda, cun gran muíño no centro da estancia e a poucos metros da cociña. Ademais de muíños, tamén aparecen morteiros de grandes dimensións para o machucado, como os documentados en María Pita-A Coruña (4), nas dúas cociñas das domus de Armea (fig. 5) ou no edificio secundario da villa de Toralla (fig. 7, f). Na domus da Roseta-Armea, o gran morteiro comparte espazo cun muíño conservado por completo, situados a carón da cociña.

Se a moenda está presente no rexistro, outras fases do proceso do pan (limpeza do gran, peneirado, torrefacción e amasado) non deixaron pegada, así como a maioría das ferramentas especializadas. Xa sinalamos a posible localización de artesas (para o amasado) sobre baseamentos pétreos nalgunhas cociñas. Namentres, nos patios das casas - como as de Armea- ou en zonas comunais -como posteriormente funcionarán as airas nas aldeas galegas- levaríase a cabo a limpeza e o peneirado dos cereais que posteriormente eran almacenados para a súa moenda. Tampouco contamos no noroeste con estruturas coñecidas da época romana tipo horreum para a almacenaxe e a conservación dos cereais, coa coñecida excepción dos horrea militares do forte romano de Aquis Querquenis e Ciadella (Sobrado dos Monxes). ${ }^{64}$ Polo contrario, si que existen para a época prerromana, como son os casos do castro da Saceda (Cualedro) ou o máis recente «hórreo» do castro do Covelo (Baños de Molgas, Ourense). ${ }^{65}$ De seguro que existiron, aínda que polo momento non as conseguimos identificar asociadas a estes espazos domésticos.

\footnotetext{
${ }^{63}$ Bustamante, Salido e Gijón, "La panificación...”, páx. 356, fig. 9.

${ }^{64}$ Datos inéditos dos autores.

${ }^{65}$ Para máis información sobre esta estrutura: Castro de Acea, dispoñible en: turismobanhosdemolgas. gal/es/item/castro-da-acea/ [consulta: 07/01/2020].
} 
Outra das actividades directamente relacionadas coas culinae debeu ser a produción doméstica de téxtiles. Así parece que o manifesta a presenza sistemática de pondera e fusaiolas nestes ambientes (p. ex.: María Pita-A Coruña (4), Iria Flavia (11), Armea (23-24) etc.).

O caso da cociña do edificio secundario de Toralla (fig. 7, d-f) é paradigmático a este respecto. Neste espazo documéntanse varios muíños e os restos dun tear con pesos (pondera) cerámicos e de laxes de lousa. Na estancia anexa -parcialmente escavada-, recuperouse un morteiro de granito de grandes dimensións. Este caso exemplifica, polo tanto, varias das actividades que se realizarían neste tipo de espazos multifuncionais. Porén, moitas outras actividades, que de seguro se desenvolverían nestes espazos (reparación de instrumentos, afumado de carnes e peixes etc.) non deixaron pegadas no rexistro arqueolóxico.

\section{CONCLUSIÓNS}

Sendo conscientes das limitacións do noso traballo, este estudo supón unha aproximación á realidade arqueolóxica dos espazos culinarios romanos de boa parte da Gallaecia. Cremos por isto que se cumpriu co obxectivo principal e abríronse, ao mesmo tempo, novas vías de traballo. Porén, falta por analizar entre outros aspectos, para a correcta caracterización destes espazos, o seu instrumentum domesticum. Só para o caso da domus do Hexáscele de Armea contamos con datos de importante valor sobre o material asociado aos niveis de uso da cociña. Por exemplo, no contorno do forno recuperáronse decenas de grandes cazolas/tapadeiras semellantes ao clibanus romano, utilizado para elaborar pan no forno ou no propio fogar, neste caso cuberto polas cinsas (fig. 5, f-g). Todo parece indicar que estas grandes cazolas se empregarían en Armea dunha forma semellante ao artefacto romano para cocer o pan, sendo habituais noutros xacementos galaicos. Pero isto e outras moitas cousas só as poderemos coñecer cun estudo sistemático do material asociado a estes espazos, que nos achegará tamén datos cronolóxicos precisos sobre a evolución dos sistemas construtivos e dos usos das cociñas durante a época romana. Tamén queda pendente un estudo pluridisciplinario dos alzados dos fornos, dos sistemas de chemineas dos fogares, dos mecanismos de cocción e mesmo o desenvolvemento de análises do tipo de combustible utilizado nestas estruturas domésticas ou dos produtos transformados, moídos ou cociñados.

Este traballo móstranos a cociña romana da Gallaecia como un espazo escuro, en penumbra e cheo de fumes da lareira e do forno, pero tamén un lugar especializado e multifuncional onde se realizaban máis tarefas cás de transformar e cociñar os alimentos. Sen dúbida funcionaban como lugar de almacenaxe, como o demostran os restos asociados de cerámicas de almacenaxe para líquidos 
(viños, aceites, auga etc.) e sólidos (cereais, manteiga, mel etc.), e outras estruturas. Tamén como lugar para conservar alimentos (carnes, peixes ou queixos) mediante a salga e/ou o afumado, xa que a presenza da lareira aseguraba a temperatura e a humidade necesaria, ademais do imprescindible contacto continuo cos fumes. Artesas, estantes e outras estruturas servían para procesar e organizar os produtos e os utensilios en cerámica e en metal necesarios. O pan cocíase nas propias lareiras ou en fornos construídos especificamente para esta función, utilizando recipientes cerámicos - grandes fontes- boca abaixo ou con tapadeiras sobre as que se dispuñan as brasas (fig. 5 , g). A fariña era obtida na propia cociña ou, cando existía, nunha estancia anexa como queda demostrado pola proliferación dos muíños nestes espazos. O cálido ambiente da cociña creaba o espazo idóneo para outros labores, como o fiado e o tecido.

As cociñas e as dependencias anexas ocupaban unha parte concreta das casas, normalmente formando un conxunto de estancias especializadas e afastadas das zonas habitacionais. Incluso en ocasións, estes espazos constrúense separados fisicamente do resto da vivenda e quedan unidas a ela mediante áreas abertas como corredores de distribución ou patios. En fin, seguen a concepción vitrubiana, ou máis ben, o «sentido común», separando as zonas con cheiros, fumes e de combustión e con maior risco de incendio, do resto da casa, minimizando así as posibilidades de que a vivenda fose consumida por un lume provocado nas lareiras e nos fornos.

Se comparamos os resultados da nosa análise co que coñecemos sobre a cociña romana de carácter mediterráneo -especialmente a caracterizada en cidades italianas - podemos comprobar que existen diferenzas e tamen semellanzas. Por exemplo, a cociña romana das casas máis pudentes sitúase nun lugar apartado, habitualmente xunto ás letrinas e as termas ${ }^{66}$, como observamos nos poucos casos galegos onde contamos con ese tipo de espazos. No entanto, o habitual é que non existan nas casas estudadas galaicas nin letrinas nin termas, polo que atopamos a cociña asociada a outro tipo de espazos, como acontece nas casas romanas máis humildes, onde o máis frecuente é que se localicen nas marxes dos espazos de recepción ${ }^{67}$. Só na villa de Toralla visualizamos a separación entre a cociña e os comedores e triclinios da que nos falan as fontes. Nesta villa a mare, o oecus e a cociña comunícanse únicamente mediante o tránsito polo seu exterior (Fig. 7).

No tocante aos fogares, as casas de Pompeia mostran un bo catálogo de fogóns elevados, incluso acompañados dun vertedoiro e cun vano abovedado na

\footnotetext{
${ }^{66}$ Fernández Vega, La casa romana..., páx. 227; Clarke: The Houses Of Roman Italy, 100 B. C-A. D. 250 Ritual, Space, And Decoration, Berkeley; Los Angeles, University of Califonia Press, 1991, páx. 14. ${ }^{67}$ Clarke, The Houses Of Roman Italy..., páx. 25.
} 
súa parte inferior para gardar a leña ${ }^{68}$. Como xa advertimos na nosa análise, só contamos en Galicia (domus do Mitreo) cun fogar sobreelevado pero sen a presenza de leñeira nin vertedoiro. Porén, o sistema do tiro e da saída de fumes, tanto na casa galaica como na romana eran similares, sendo moi pouco habitual a existencia de chemineas ${ }^{69}$. Tamén en Italia, os fumes saían ao exterior entre as propias tellas ou a través dalgún oco ou fiestra na parede, apertura que tamén servía para avivar o lume. Asimesmo, é salientable a pouca presenza de fornos nas casas itálicas, innecesarios debido a existencia de padarias "industriais" que abastecían á cidade $^{70}$. Só en casos puntuais podería incluirse un forno como elemento da culina, algo que, como puidemos ver nos casos galegos, marca unha diferenza aparecer con frecuencia nos espazos culinarios mellor conservados do noso estudo.

Por último, cabe sinalar un aspecto no que non puidemos afondar por falla de datos no rexistro: a sacralidade do espazo culinario. Os lararios marcan as pautas de ritualidade nas casas romanas localizándose maioritariamente nun esquinal do atrio e na cociña ${ }^{71}$. Por desgraza, non contamos con datos suficientes como para outorgarlle aos espazos culinarios estudados a función que xogarían na ritualidade da vida na vivenda. Queda polo tanto, outro aspecto no que afondar para o futuro, sempre e cando os datos arqueolóxicos o permitan.

\section{BIBLIOGRAFÍA}

Acuña Piñeiro, Ángel; Pérez Losada, Fermín e Paz Lobeiras, Rosa María, "Nuevas aportaciones al Vigo romano", en Congreso Internacional "As orixes da cidade no Noroeste Hispánico”, comunicación oral non publicada en actas, 1996.

Alcorta Irastorza, Enrique, LVCVS AVGVSTI II. Vol. 2. Cerámica común romana de cocina y mesa hallada en las excavaciones de la ciudad, A Coruña, Fundación Pedro Barrié de la Maza, 2001 (Catalogación arqueolóxica e artística de Galicia).

Barba Seara, Carlos Hugo e Pérez López, David, "O castro de Armea e a súa evolución na cultura castrexa: intervencións arqueolóxicas 2011 a 2014”, Boletín Auriense, 46 (2016), páxs. 59-102.

Barreiro Barral, José, "Por tierras de Céltigos: Grandimirum o Brandomil”, La Voz de Galicia (07-11-1972).

Bartolomé Abraira, Roberto; Alcorta Irastorza, Enrique e Santamaría Gámez, Guillermo, "Escavación arqueolóxica en área dos soares núms. 68-70 da rúa Nova en Lugo, avance de resultados", CROA: Boletín da Asociación de Amigos do Museo do Castro de Viladonga, 20 (2010), páxs. 14-49.

\footnotetext{
${ }^{68}$ FernÁndez VegA, La casa romana..., páx. 231.

${ }^{69}$ FERnÁNDEZ VEGA, La casa romana..., páx. 231.

70 Fernández Vega, La casa romana..., páx. 232.

${ }^{71}$ Clarke, The Houses Of Roman Italy..., páx. 9; Correia: Arquitectura Doméstica de Conimbriga..., páx. 281.
} 
Bustamante, Macarena; Salido, Javier e Gijón, Eulalia, "La panificación en la Hispania romana”, en Macarena Bustamante-Álvarez e Darío Bernal Casasola (coords.), Artífices idóneos: artesanos, talleres y manufacturas en Hispania, Madrid, CSIC, 2014 (Anejos de Arquivo Español de Arqueología, 719), páxs. 333-368.

Caamaño Gesto, José Manuel, "Excavaciones en el campamento de Cidadela (A Coruña)", Brigantium, 12 (2000), páxs. 199-208.

Calo Ramos, Nuria, "Proxecto de excavación en área e control arqueolóxico no soar núm. 59 da rúa da Ferreiría", en Actuacións arqueolóxicas. Ano 2007, Santiago de Compostela, Xunta de Galicia, 2009, páxs. 179-180.

Carlsson-Brandt Fontán, Erik, "La villa romana de Porta de Arcos (Rodeiro, Pontevedra): 45 años de investigación arqueológica", Férvedes, 8 (2015), páxs. 267-275.

Carreño Gascón, Covadonga, Campaña de excavación arqueológica en el Campo da Forca. Lugo. 1990, 1990 [informe depositado na Dirección Xeral de Patrimonio Cultural da Xunta de Galicia].

Carreño Gascón, Covadonga, "Memoria de los sondeos arqueológicos realizados en el entorno del antiguo matadero municipal, Lugo", Larouco: revista anual da antiguidade galai$c a, 5$ (2010), páxs. 121-148.

Clarke, John R., The Houses Of Roman Italy, 100 B. C-A. D. 250 Ritual, Space, And Decoration, Berkeley; Los Angeles, University of Califonia Press, 1991.

Correia, Virgilio Hipólito, A Arquitectura Doméstica de Conimbriga e as Estruturas Económicas e Sociais da Cidade Romana, Coimbra, Centro de Estudos Arqueológicos das Universidades de Coimbra e Porto, 2013 (Conimbriga, Anexos, 6).

Currás Refojos, Brais Xosé, Transformaciones sociales y territoriales en la cuenca del Baixo Miño entre la Edad del Hierro y la integración en el Imperio romano, tese de doutoramento, Universidade de Santiago de Compostela, 2012.

Díaz García, Fructuoso, O mundo antigo no Museo Massó e a romanización en Bueu, Santiago de Compostela, Xunta de Galicia, 2015.

Eguileta Franco, José María e Rodríguez Cao, Celso (coords.), Aqva, divi, vrbs. Auga, deuses e cidade. Escavacións arqueolóxicas nas Burgas (Ourense) Casa dos Fornos e Traseiras das rúas do Vilar, Cervantes e do Baño, Ourense, Concello de Ourense, 2012.

Fernández Fernández, Adolfo, El comercio tardoantiguo (ss. IV-VII) en el noroeste peninsular a través del registro cerámico de la ría de Vigo, Oxford, Archaeopress, 2014 (Roman and late antique Mediterranean pottery, 5).

Fernández Fernández, Adolfo, Memoria interpretativa. Sondaxes arqueolóxicas e de conservación básica no castro de Armea (Allariz, Ourense). Campaña 2014, 2019 [memoria depositada no Servizo de Arqueoloxía da Xunta de Galicia].

Fernández Fernández, Adolfo e Pérez Losada, Fermín, A Cibdá de Armea I. Escavacións no xacemento galaico-romano do Monte do Señoriño, Vigo, Servizo de Publicacións da Universidade de Vigo, 2017.

Fernández Ochoa, Carmen; Gil Sendino, Fernando e Orejas Saco del Valle, Almudena, "La villa romana de Veranes. El complejo rural tardorromano y propuesta de estudio del territorio", Archivo Español de Arqueología, vol. 77, núm. 189-190 (2004), páxs. 197-219.

Fernández Vega, Pedro Ángel, La casa romana, Madrid, Akal, 1999. 
Ferrer Sierra, Santiago e González Fernández, Enrique, Memoria da escavación arqueolóxica de urxencia no solar da rúa do Xeral Tella, esquina rúa de Ribadeo, da cidade de Lugo. 1992, 1992 [informe depositado na Dirección Xeral de Patrimonio Cultural da Xunta de Galicia].

Ferrer Sierra, Santiago, "Escavación arqueolóxica no campamento romano de Aquis Querquennis, Bande (Ourense)”, en Actuacións arqueolóxicas. Ano 2007, Santiago de Compostela, Xunta de Galicia, 2009, páxs. 54-55.

Ferrer Sierra, Santiago, "Recentes intervencións arqueolóxicas no campamento militar de Aquis Querquennis (Bande, Ourense)", Larouco, 5 (2010), páxs. 163-166.

Gijón Gabriel, María Eulalia e Bustamante Álvarez, Macarena, "Los sellos romanos de panadero: una aproximación a su estudio a partir de los depositados en el Museo Nacional de Arte Romano (Mérida)", Huelva en su historia, 13, (2010), páxs. 15-30.

González Fernández, Enrique, Excavación arqueolóxica de urxencia no solar da rúa Nova, 19, esquina rúa da Tinería, Lugo. Informe preliminar e valoración cientifica, 1992 [informe depositado na Dirección Xeral de Patrimonio Cultural da Xunta de Galicia].

López González, Luis Francisco, Memoria da excavación de urxencia no xacemento romano de Quintá de Agrade (Chantada, Lugo), 1991 [memoria inédita depositada no Servizo de Arqueoloxía da Dirección Xeral do Patrimonio Cultural da Xunta de Galicia].

López González, Luis Francisco e Álvarez González, Yolanda, Informe preliminar da excavación en área no xacemento romano de Iria Flavia (Padrón, A Coruña), 1994.

López Pérez, María Catalina e Tomás Botella, Víctor, "La vajilla fina de mesa de época romana en los solares núm. 10-12 de la calle Tabernas (A Coruña)", Gallaecia, 29 (2010), páxs. 173-190.

López Pérez, María Catalina e Vázquez Collazo, Santiago, "La mesa y la villa romana de O Cantón Grande (A Coruña): aproximación al yacimiento a través de la Terra Sigillata", Gallaecia, 26 (2007), páxs. 85-108.

Magalhaes, Fernanda Eugénia Puga, A domus romana no Noroeste Peninsular. Arquitetura, construção e sociabilidades, Tese de doutoramento da Universidade do Minho, Braga, 2019.

Meijide Cameselle, Gonzalo e Acuña Castroviejo, Fernando, Memoria preliminar de la $4 .^{a}$ campaña de excavaciones arqueológicas en el castro de A Graña, castro de Piñeiro y agro de Nogueira (Toques, A Coruña), 1990 [memoria inédita depositada na Biblioteca da Facultade de Xeografía e Historia da Universidade de Santiago de Compostela].

Meijide Cameselle, Gonzalo e Acuña Castroviejo, Fernando, Memoria preliminar de la $5{ }^{a}$ campaña de excavaciones arqueológicas en el castro de A Graña y agro de Nogueira (Toques, A Coruña), 1991 [memoria inédita depositada no Servizo de Arqueoloxía da Dirección Xeral do Patrimonio Cultural da Xunta de Galicia].

Montes López, Rubén e Villa Valdés, Ángel, "Una domus altoimperial en el castro de Chao Samartín (Asturias): quién, cómo y porqué”, Férvedes, 8 (2015), páxs. 277-284.

Naveiro López, Juan Luis, “Arqueología urbana en A Coruña y definición del asentamiento romano", en Ramón Villares Paz (ed.), La ciudad y el mundo urbano en la Historia de Galicia, Santiago de Compostela, Tórculo Eds., 1988, páxs. 35-62.

Nieto Muñiz, Eduardo Breogán, "Escavación arqueolóxica en área no soar núm. 5 da rúa de Romero Nieto, Xinzo de Limia”, en Actuacións arqueolóxicas. Ano 2007, Santiago de Compostela, Xunta de Galicia, 2009, páxs. 164-165. 
Nión Álvarez, Samuel, "Brigantium no século xxI: aproximación aos últimos datos arqueolóxicos da ocupación galaicorromana na cidade da Coruña (s. I-IV d. C.)”, Gallaecia, 37 (2018), páxs. 39-79.

Orero Grandal, Luis, "Intervención arqueolóxica nas inmediacións das Burgas: patio do colexio das Josefinas", Boletín Auriense, 27 (1997), páxs. 107-146.

Orero Grandal, Luis, "Actuacións arqueolóxicas na cidade de Ourense: colexio das Madres Xosefinas e Xardín do Posío", en Ourense. A cidade, da orixe ao século XVI, Ourense, Museo Arqueolóxico Provincial de Ourense, 2009, páxs. 33-44.

Paz Lobeiras, Rosa María, Memoria da escavación arqueolóxica en área no soar núm. 65 da rúa do Conde de Torrecedeira (Vigo), 1998 [memoria inédita depositada no Servizo de Arqueoloxía da Dirección xeral do Patrimonio Cultural da Xunta de Galicia].

Pérez Losada, Fermín, "Escavación arqueolóxica, prospección xeofísica e consolidación da villa romana de Noville (Mugardos, A Coruña)", en Arqueoloxía-Informes 3. Campaña 1989, Santiago de Compostela, Xunta de Galicia, 1995, páxs. 51-56.

Pérez Losada, Fermín, "Xacemento de Noville: unha villa romana costeira na villa de Ferrol”, Brigantium, 12 (2000), páxs. 219-226.

Pérez Losada, Fermín, "Entre a cidade e a aldea. Estudo arqueohistórico dos "aglomerados secundarios" romanos en Galicia", Brigantium, 13 (2002), páxs. 15-348.

Pérez Losada, Fermín; Naveiro López, Juan; Doval Galán, Francisco; Castro Pérez, Ladislao; Vázquez Varela, José Manuel e Fernández Rodríguez, Carlos, "Estudo do material arqueolóxico procedente da villa romana de Noville (Mugardos, A Coruña)", Minius, 1 (1992), páxs. 57-88.

Pérez Losada, Fermín; Vieito Covela, Santiago e Fernánez Fernández, Adolfo, "Resultados preliminares das escavacións arqueolóxicas na "villa" romana de Toralla (Oia, Vigo)", Castrelos: revista do Museo Municipal Quiñones de Leon, 13 (2007), páxs. 12-25.

Ramil González, Emilio e Caamaño Gesto, José Manuel (2010), "Escavación arqueolóxica e limpeza no campamento romano de Cidadela. Campaña 2009”, en Actuacións arqueolóxicas. Ano 2009, Santiago de Compostela, Xunta de Galicia, 2010, páxs. 47-48.

Ricart Guillot, Susana, El yacimiento romano de Caldoval, Mugardos, A Coruña, 2014 [memoria técnica depositada no Servizo de Arqueoloxía da Dirección Xeral do Patrimonio Cultural da Xunta de Galicia].

Rodríguez Cao, Celso (coord.), A domus do Mitreo, Santiago de Compostela, Universidade de Compostela, 2011.

Rodríguez Colmenero, Antonio, Lvcvs Avgvsti: la ciudad romano-germánica del Finisterre Ibérico. Génesis y evolución histórica (14 a. C.-711 d. C.), Lugo, Concello de Lugo, Servizo Municipal de Arqueoloxía, 2011.

Rodríguez Colmenero, Antonio; Ferrer Sierra, Santiago e Hervés Reigoso, Francisco, "El complejo arqueológico romano de Aquis Querquennis, Porto Quintela (Ourense)", en Antonio Rodríguez Colmenero (coord.), Los orígenes de la ciudad en el noroeste hispánico: actas del Congreso Internacional. Lugo 15-18 de mayo de 1996, Lugo, Deputación Provincial, 1999, páxs. 891-910.

Rodríguez Colmenero, Antonio e Ferrer Sierra, Santiago (eds.), Excavaciones arqueológicas en "Aquis Querquennis". Actuaciones en el campamento romano (1975-2005), Lugo, Grupo Arqueolóxico Laurouco, 2006. 
Rodríguez González, Xulio, Conxunto arqueolóxico de Santomé. Guía arqueolóxica, Ourense, Museo Arqueolóxico Provincial de Ourense, 2000.

Rodríguez Nóvoa, Alba Antía, Yacimientos castrexos de la cuenca del Miño: análisis de la cerámica indígena, tese de doutoramento, Santiago de Compostela, Universidade de Santiago de Compostela, 2019.

Villar Quintero, Rosa, "Escavación arqueolóxica en área na rúa de Tomás Mirambel, núm. 8, Panxón, Nigrán”, en Actuacións arqueolóxicas. Ano 2006, Santiago de Compostela, Xunta de Galicia, 2008, páxs. 159-160.

Xusto Rodríguez, Manuel, "O núcleo urbano de Xinzo e as súas orixes romanas", en Antonio Rodríguez Colmenero (coord.), Los orígenes de la ciudad en el noroeste hispánico: actas del Congreso Internacional. Lugo 15-18 de mayo de 1996, Lugo, Deputación Provincial de Lugo, 1999, páxs. 1291-1304.

Xusto Rodríguez, Manuel, “A villa romana de Riocaldo: estado da cuestión”, Brigantium, 12 (2000), páxs. 227-246.

Villa Valdés, Ángel, Montes López, Rubén e Gago Muñoz, Olga, Domvs. Una casa romana en Castro del Chao San Martin. Exposición temporal y ciclo de conferencias, Gijón, Consellería de Educación e Cultura, 2006. 